\title{
The Poiesis of Everyday Life and Space in Yüksel Street*
}

\author{
Yüksel Caddesi’nde Gündelik Hayatın ve Mekânın Yaratımı ${ }^{* *}$
}

\section{Duygu CIHANGER RIBEIRO}

Faculty of Engineering and Architecture, Department of Architecture and Urban Planning, Gent University, Belgium

duygu.cihanger@gmail.com

ORCID ID: 0000-0001-7642-2486

DOI: $10.5505 /$ jas.2019.63825

\begin{abstract}
The premeditated decisions of urban plans and designs are in a continuous transformation due to the everyday expectancies and needs of users. People mostly intervene in their built environment in differing scales and temporalities which simultaneously transform a designed space and making it closer to a lived space. Therefore, the emergent user spaces and social practices that occur throughout the everyday life dynamics beyond the expectations of an urban plan are significant to develop a human-centered viewpoint for urban planning and design studies. This study aims at unfolding the theoretical and empirical dimensions of the usually overlooked everyday space and practices which are mostly categorized as ordinary or temporary. In this context, a field study in Yüksel Street has been undertaken to to frame the theoretical discussion on the social and spatial production of urban space and everyday life from an urbanism perspective. The site is a vibrant urban space located in the city center of Ankara that is called Kizılay. Yüksel is a well-connected street to the public transportation stops and has a diverse land use. Since it was laid out following the urban plans in the early years of Republic, the street has been facing social, economic and physical alterations bringing dialectics of designed and lived space together. Despite the initial street pattern maintains today in morphological sense, the altering faces of everyday life and its temporal, spatial and societal impact result in a multi-layered urban entity. This study proposes a theoretical approach which is beyond the dualities and conflicts between physical or social space and temporary or permanent urban rhythms to understand the poiesis of everyday life and space. In this context, there are two channels of study. The first one is using both the archival data on the urban infrastructure of memory (the memory of the past), then the second is to unveil the poiesis of everyday life and space through a field research on Yüksel Street that would make the fluid archive of the ordinary practices and aesthetics (memory enacted in the present). The corresponding research methods on the ethnographic and spatial-visual analysis strengthen the unbreakable bond between social and spatial. The outcomes of the study present the role of the everyday user and the changing urban rhythms on the production of space. This connecting approach explores and presents the spatial qualities of public life practices which are usually labeled as left-over spaces and taken for granted for being evasive or temporary. The dialectic of social life and urban design is essential to grasp user preferences and expectancies from their contribute to the humanoriented urbanism studies.
\end{abstract}

Keywords: Everyday life, Public space, Urban street, Urban design, Rhythmanalysis, Lived space, Yüksel Street, Ankara

* This research was awarded by Koç University-VEKAM Library and Archive Research Award in 2017. This article covers the initial theoretical discussions and preliminary findings of the field study pursued for the Ph.D. thesis of the author, entitled "Spontaneity and Urban Design: Exploring Everyday Life Practices and the Formation of Lived Space in Yüksel Street" supervised by Prof.Dr. Pieter Uyttenhove in the Department of Architecture and Urban Planning in Ghent University (BOF Scholarship), and co-supervised by Prof.Dr. H. Çağatay Keskinok in the Graduate Program of City and Regional Planning in the Middle East Technical University.

** Bu araștırma 2017 yılı Koç Üniversitesi-VEKAM Kütüphanesi ve Arșivi Araștırma Ödülü’nü kazanmıștır. Makale, Gent Üniversitesi Mimarlık ve Şehir Planlama Bölümü’nde BOF burslusu olarak, Prof.Dr. Pieter Uyttenhove danışmanlığında ve Orta Doğu Teknik Üniversitesi Şehir ve Bölge Planlama Doktora Programı’nda, Prof. Dr. H. Çağatay Keskinok eş-danışmanlığında gerçekleştirilen, yazarın "Spontaneity and Urban Design: Exploring Everyday Life Practices and the Formation of Lived Space in Yüksel Street" başlıklı doktora tezindeki öncül kuramsal tartışmaları ve alan çalışmasının ilk bulgularını içermektedir. 


\section{Öz}

Şehir planları ve kentsel mekân tasarımları, kullanıcıların gündelik hayatlarında beklentileri ve ihtiyaçları doğrultusunda sürekli bir dönüşüm içerisindedir. İnsanlar bu süreç içerisinde kentsel planın fiziksel düzenine tamamen bağlı kalmadan genellikle küçük ölçekli yeni kullanımlar ve mekânlar üretir. Bu nedenle, resmî olarak planlanmamış ancak gündelik hayat dinamikleriyle ortaya çıkan kullanıcı mekânları ve toplumsal etkinlikler, kentsel planlama ve tasarım araştırmalarının insan odaklı yeni bakış açısını geliştirmek adına oldukça önemlidir. Çalışmanın amacı, gözardı edilen, sıradan ve geçici olarak adlandırılan mekânsal pratikleri insan-odaklı bir yaklaşımla kuramsal ve görgül boyutlarıyla ele almaktır. Bu bağlamda, yaşanan mekân ve mekânın toplumsal üretimi kavramları çerçevesinde Yüksel Caddesi’nde bir alan çalışması yürütülmüştür. Ankara’nın kent merkezi olarak kabul edilen Kızılay semtinde yer alan Yüksel Caddesi, çeşitli toplu taşıma bağlantılarına yakınlığı, yaya bölgesi olması ve zengin arazi kullanım yapısıyla şehrin en kalabalık sokaklarındandır. Ankara’nın Cumhuriyet dönemi ilk planlama çalışmalarından itibaren varolan sokak, hem kentsel planlama ve tasarım hem de sosyo-ekonomik anlamda birçok farklı dönem geçirmiştir. Yapılı çevre hâlâ ilk tasarlanan sokak dokusunun izlerini taşımasına rağmen gündelik hayatın değișen yüzleri, kentsel mekânın zamansal ve toplumsal çok katmanlı yapısını ortaya çıkarmaktadır. Bu araştırma, mekânın fiziksel üretimi ile birlikte, toplumsal yaratımını (poiesis) anlamak için fiziksel veya toplumsal olarak üretilen mekân, geçici veya kalıcı kentsel ritimler gibi ikililiklerin ötesinde bir kuramsal bakış açısı önerir. Bu bağlamda çalışmada iki temel odak bulunmaktadır. Bunların ilki, hafızanın kentsel altyapısını (geçmişin hatırasını) anlama amacıyla arşiv verilerini derlemek, daha sonra gündelik yaşamın ve mekânın poiesisini tartışabilmek için (günümüzde mevcut olan bellek) Yüksel Caddesi’ndeki gündelik hayatın kentsel ritimlere ve kullanıcılara odaklanarak gözlemlenmesidir. Bu doğrultuda takip edilen etnografik ve mekânsal-görsel analiz yöntemleri, mekânsal ve toplumsal olanın koparılamaz ilişkisini görgül sonuçlarla desteklemektedir. Sonuçlar, gündelik hayatın kullanıcılarının ve değişen ritimlerinin ve kullanıcıların rolünün mekânın üretimindeki önemini gözler önüne sermektedir. Bu birleştirici yaklaşım, göz ardı edilen, atıl olarak adlandırılan kullanıcı mekânlarının, anlık ya da geçici oldukları gerekçesiyle hafife alınan kamusal hayat pratiklerinin mekânsal niteliklerini vurgulamaktadır. Kentsel mekânda, tasarım ve sosyal yaşamın dialektiği, kullanıcı tercihlerinin fiziksel alan üzerindeki etkilerinin anlaşılması ve insan odaklı şehircilik çalışmalarına katkı sunmaktadır.

Anahtar sözcükler: Gündelik hayat, Kamusal alan, Kentsel sokak, Ritimanalizi, Yaşanılan mekân, Yüksel Caddesi, Ankara

\section{Introduction}

People humanize urban places as they live and generate the social and physical layout of cities. The poiesis, as a concept, helps to explain this social and spatial making of urban space emphasized in this research. Giorgio Agamben eloquently states that "...man has on earth a poetic, that is, a productive, status" (1999, p. 42). The Greek root of the word poetics is poiein refers to making but not in the sense of object production but of the essence of any work. Similarly, the expression of "the poetry in men's dwelling" (Heidegger, 1971, p. 213) states that there is something active in living in space beyond filling in an already existing physical container. Therefore, urban space is beyond an independent material reality or as a "design intention from which the social effect will simply follow" (Borden, 2001, p. 4). Thus, the physical production of urban space merely is inseparable from human use and action (Shields, 1999, p.146). Despite different frameworks, the togetherness of plan and living processes is central to urbanism studies for which Jean-François Augoyard (2007, p.9) states: "Now, as it turns out, once the project is fulfilled and built, nothing happens as planned." From a theoretical perspective, the social production of space has been studied extensively by prominent scholars of urban sociology (Soja, 1996/1980; Shields, 1999; Elden, 2004; Merrifield, 2006; Stanek, 2011) from a philosophical stance. From an urban design viewpoint, there are studies emphasizing the link between social and physical dimensions of urban space as well (Boudon, 1972; Whyte, 1980; Cuthbert, 2007; Madanipour, 1996; Franck and Stevens, 2007; Aelbrecht, 2016).

The dialogue between the planned and lived processes as well as the physical production and social reproduction of space necessitate dialectical thinking for urbanism. For instance, a triadic approach links the "physical space (nature), mental space (formal abstractions about space), and social space (the space of human interaction)" (Merrifield, 2006, p. 20). Therefore, Henri Lefebvre (1991a, pp. 38-39) suggests three interrelated aspects of space which are conceived (representation of space), perceived (spatial practices) and lived (spaces of representation). Conceived space is the dominant space that is produced by planners and engineers. Perceived 
space is the practical basis of the perception of the outside world with its routines and networks. Being objective and empirically measurable "spatial practices" offer input for material analysis as mappings. The final interrelated aspect comprises the lived space which is the space of inhabitants and lived experience. Despite the difference between the first two is blurred; the lived space is distinct from them. Lived space that "overlays physical space, making symbolic use of its objects, and tends towards more or less coherent systems of non-verbal symbols and signs," is a sociological concept that has been coined by Lefebvre (1991b) and further developed by several researchers as Edward Soja (1996) and Łukasz Stanek (2011).

From an urban social theory and design perspective, this study argues that lived space embody morphological traces and design qualities despite mostly being presented as a sociological and political concept emphasizing the lived traces even in the most controlled and planned urban spaces. The lived space or the third space as coined by Soja (1996) bears many possibilities for new ideas, critical thinking and the meetings of the two opposites. In the context of this research, lived space refer to the spaces made by people (Cihanger, 2018) overlaying the premeditated urban layout and it aims to overcome the dominance of space of urban professionals (conceived space) through exploring the ordinary designs by everyday users (lived space). Some studies conceptualize the spatial dimension of lived space with the differences in their approaches to the temporality, quality, and reasoning. For instance, Ian Bentley (1985, p. 99) categorizes the processes in which people express themselves in the urban space as (affirmative and remedial) personalization. Similarly, Christopher Alexander (1979), puts the living patterns as the essentials for a place to gain quality. From a more social and cultural point of view, John Habraken (1998) uses vigorous concepts as inhabitation, live configuration to explain any grouping of parts under the control of a single agent.

This study contributes to the urban social theory with an empirical approach to explore the post design processes and the role of everyday life, users and time in the planned and designed urban layouts. It postulates that social life has spatial patterns, and spatial patterns acquire social meanings through the refinement of the concepts of everyday life, social production of space and lived space from an urban design perspective. This connection is discussed via the concept of spatial dialectics that "defends an urban space in which everyday perception, spatial theory and lived space merges" (Shields, 1999). Thus, the tangible (physical) and intangible (social) values of urban form, the role of the everyday user are of utmost importance throughout the study. Aiming to explore the tangible and intangible traces of everyday life, this research asks the question of "What can be learned from the everyday users' social practices and physical imprints in the formation of an urban street?" In this context, Yüksel Street in the center of Ankara (Turkey) embodies the deliberate policies of urban planning and unpremeditated revelations of social life and thus provides an opportunity to discuss the social and physical making or poiesis of everyday life and space.

\section{Poiesis of Everyday Life and Space in Yüksel Street}

Recently, everyday life has become a central concept to study the social realities of space (Jones, 2018). In the sense of unfolding the ethnographies of urban space, everyday life is a fundamental concept in this research since it ties together the actors, spatial scales and urban temporalities in the ethnographic study in Yüksel Street. As a theoretical concept, everyday life is addressed in many fields including economy-politics, sociology, and culture (Lefebvre, 1991a; Vaneigem, 1983; Certeau, 1984; Highmore, 2002). Lefebvre debates that "everyday life as a lived experience embodies energy within itself that could be used to transform it" (Highmore, 2002; Lefebvre, 1991a). This transformation from within is maintained by everyday life embracing both ordinary and extraordinary; the boredom of repetition and endless cycles of routines, as well as the surprises. Therefore, to attain the interaction between people and their physical space beyond the premeditated physical planning, everyday life becomes an essential phenomenon.

Site Selection: Urban streets support the discussion on linking the social and spatial realities since they allow people to be outside (Jacobs, 1961) and they "are the product of design and locus of social practice." (Çelik, Favro, Ingersoll, 1994, p.1). Yüksel Street, as one of the planned streets of Ankara, has faced many alterations since it is developed in the early 1930s and it is still one of the vital pedestrian streets in the heart of the city center supported by a diverse set of land uses generating an ever-changing and vibrant social life. The location of Yüksel at the heart of Ankara which is a central urban 
area called Kızılay or Yenişehir (Newcity) is one of the most important reasons for its dynamic user profile and land use pattern (Figure 1). Considering that Kizılay is the only transportation hub for the entire city that is populated by more than five million people, both a Metro Exit and the bus stops along the boulevard make Yüksel the entrance point to a central pedestrianized zone. Consequently, the diversity in commercial activities is mesmerizing. The number and size of signboards give clues regarding this fact since they cover a wide range of businesses from a dentist, beauty salon, cafés, travel agencies, notaries, translations bureaus, English language schools, fortune-telling cafés, teahouses, local unions, and many other examples.

Research Methods and Units: Everyday life has a contradictory and complex nature that can be positioned around three framing topics as set by Ben Highmore (2002): archive, aesthetics, and practices (critiques).
These topics are as a result of an intensive literature survey conducted by Highmore (2002) covering scholars such as George Simmel, Walter Benjamin, Henri Lefebvre and Michel de Certeau who are fundamental scholars in the development of the concept of everyday life. However, this study reframes these topics to respond to its research objectives to grasp the urban context both the past and present conditions. Since everyday life is composed by the memory of the past and memory enacted in the present as discussed by Augoyard (2007), there are two overlapping historical perspectives in to study the making of everyday life and space of Yüksel Street. These two temporalities cover the main questions regarding the study of everyday life as follows:

\section{The memory of the past}

Archive (political, economic, social and morphological development in history)

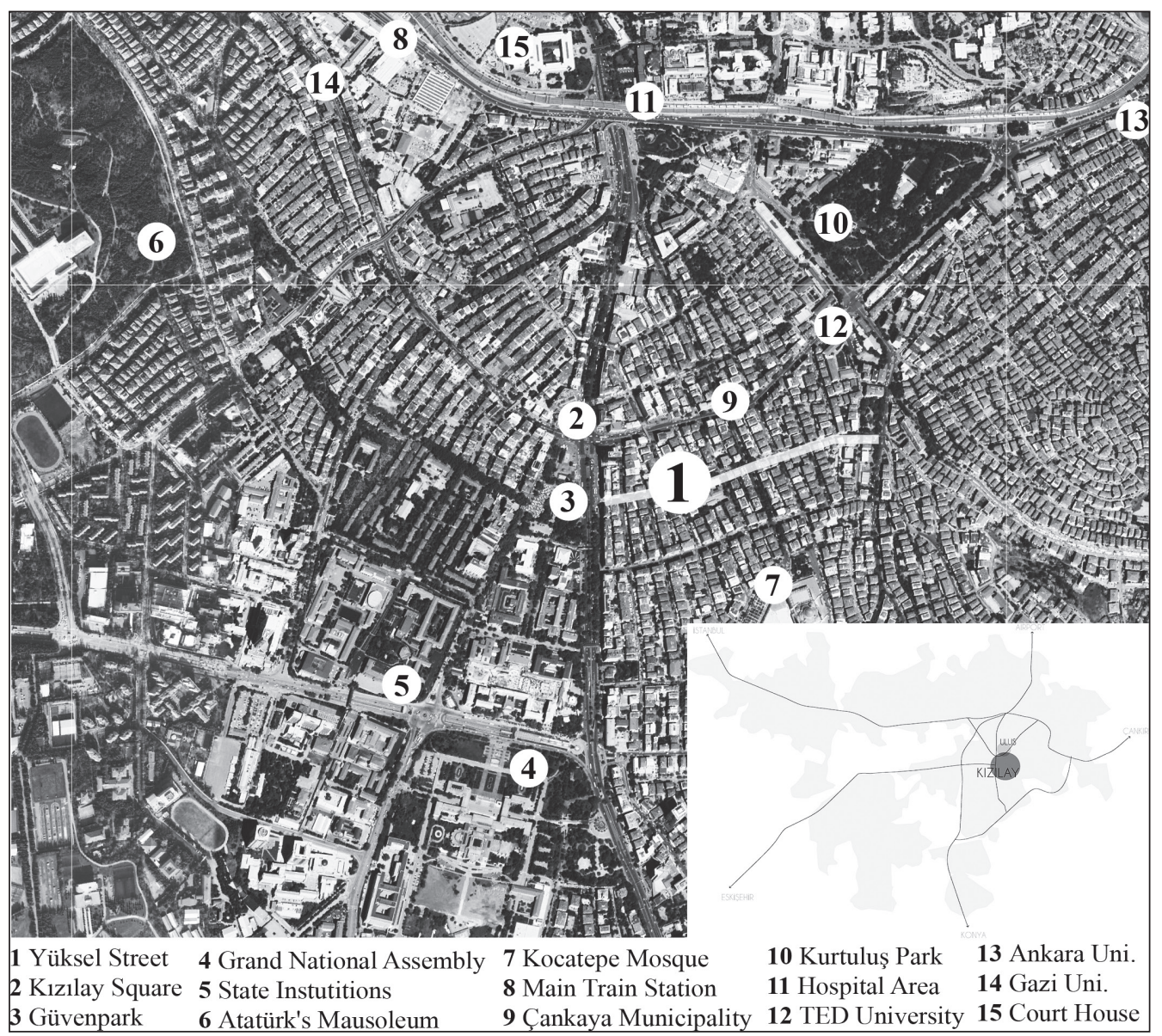

Figure 1. Yüksel Street and the Kizllay city center area in Ankara. Source: Google Earth, October 2018, bottomright image indicates the city form and the location of Ulus and Kızılay. 


\section{Memory enacted in the present.}

Practices (everyday actors and flow of time)

Aesthetics (qualities of the social and spatial practices of the ordinary)

The dialectical approach to spatial conditions and social practices requires a link between the descriptive nature of the social history revealed through ethnographic analysis methods and the spatial analysis tools such as morphological study and spatial-visual analysis. The first step of research explains the memory of the past by reviewing the history of the urban setting. The archive unfolds the records of the street's planning history, socioeconomic revelations, and the impact of local and global politics. The archival visual (maps, plans, photographs) and textual data (novels, memoirs, poetry books) is gathered from the city archives such as Koç University Vehbi Koç Ankara Studies Research Center (VEKAM) and Middle East Technical University (METU) Faculty of Architecture Maps and Plans Documentation Unit as well as METU Library. The data analysis of urban morphology (physical) is merged with a narrative analysis (social) from history books, memoirs and literary works as poems.

For the memory enacted in the present, multiple visits to the site are realized in a photographic survey which is supported by the on-site drawings and informal conversations with users. The urban street ethnography includes a detailed field study between March 2017 and March 2018 in Yüksel Street including walk-by observations, long-term observations, extensive field notes, on-site drawing, photography and unstructured conversations with the users. The findings are represented in this research through excerpts from the field notes, visual analysis on photography, drawing, and mapping. Following this, practices, which lexically mean an actual application or use of an idea, encapsulate the activities, behaviors of people in Yüksel Street. Therefore, the data is studied through an introductory rhythmanalysis covering constant, transient rhythms and ruptures. Lastly, the aesthetics refers to the "meaningful elements attributable to everyday life" (Highmore, 2002, p.19) and covers ordinary spaces indicating design qualities emerged through the use by people. As a continuum of the data analysis after the field visits, the empirical findings are evaluated from an urban design perspective as well.

\section{The Memory of the Past: Archive}

Due to human influence and alterations in the economic, cultural and ecological contexts, any physical setting is subjected to transformation, and Yüksel Street is not an exception (Figure 2). While the two-dimensional street layout and three-dimensional building setting have transformed, the socio-political and economic context was dialectically altering. The street moved from a silent and unbuilt area to a dynamic, crowded and densely built up and used site. In this context, the archive unfolds the periods of the urban development history of Yüksel according to the primary identifiers. This identifier can be a material reality that defines the city at that time or a metaphor unveiling the urban fabric in morphological terms together with underlying social and economic reasons and political tendencies. This section is significant to present the complex and particular relations composing the everyday social life and built environment in Yüksel today. The emphasis on linking the social and physical continues on this section as the periods are presented in urban morphology analysis, old photographs, and excerpts from literary works as novels and poems.

Mud and Cobblestones: During the 1920s, in the midst of the foundation of the Republic of Turkey, Ankara was a modest town with a humble lifestyle, architecture and built environment. Selma Hanım (Lady Selma), who is the main character of Karaosmanoğlu's novel on Ankara (1934/1981, p. 42) describes Ankara in that time as: "This city, located in the middle of a desert and had no difference from a piece of rock, has something that influences people; something that attracts them without anyone noticing." The daily life of people was tightly attached to the houses and public spaces in and around the Ankara castle. This tranquil life was enriched with the short-time migrations to the vineyards during summer which was not only a free time but also a working period that the families made a living and got ready for the winter (Güneş, 2013, p.15). The spatial traces such as crooked and narrow streets covered in mud and cobblestones, the handicrafts overflew to these streets from the shops, stroke Eugene Lansere (2004, p. 22), who was a Soviet painter visited the city in 1922 :

Although no one conquered their land since the time of Timur, the lack of decorations and embellishments in the houses and furniture is striking. There seems 


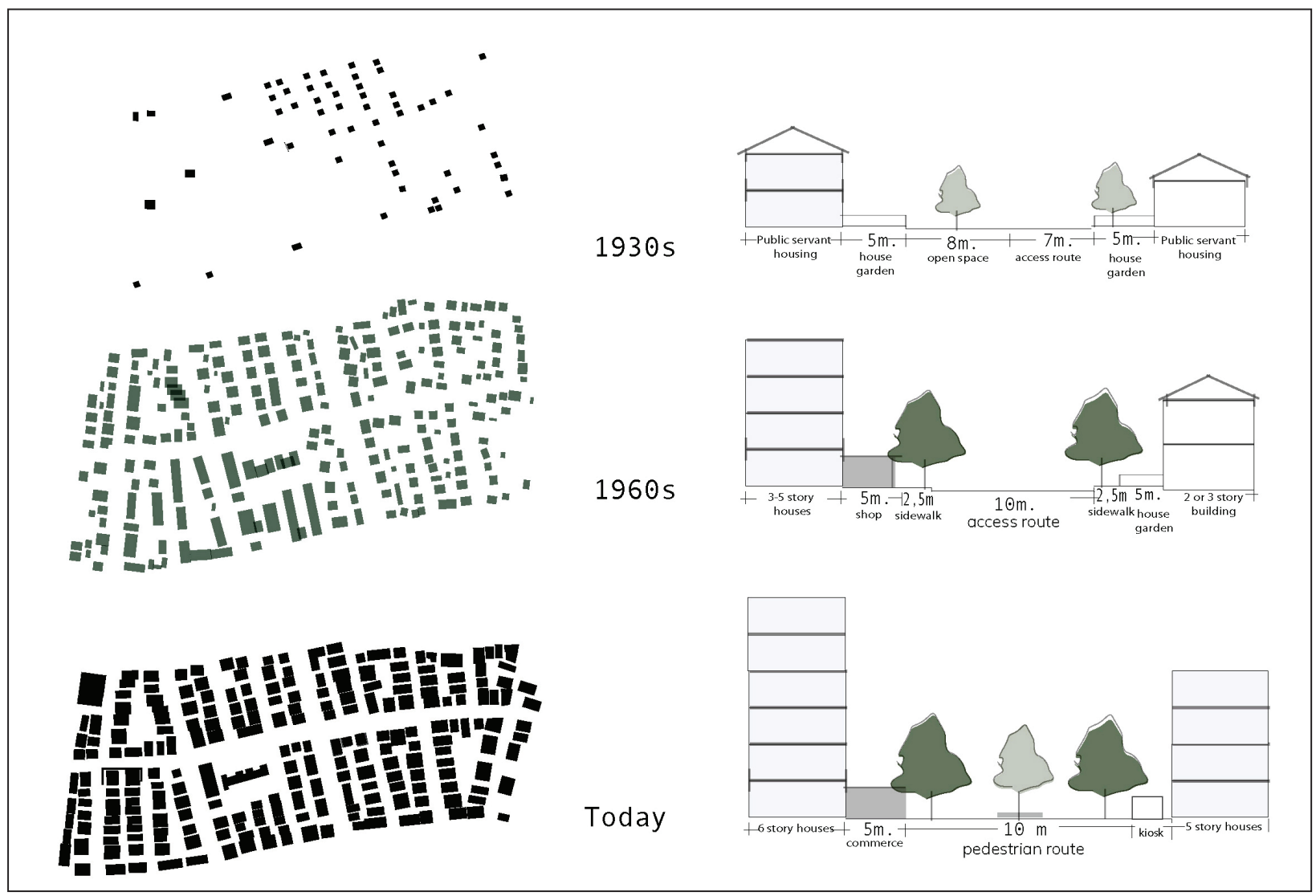

Figure 2. The incremental urban transformation of Yüksel Street.

Source: Maps on the left: METU Faculty of Architecture Maps and Plans Documentation Unit and Google Earth, 2017, Drawings by Duygu Cihanger Ribeiro.

to be nothing attractive. The people go walking in the evening; they walk to the lakes where there are tables along the water or to the barracks serving tea or coffee near the water streams.

Built within the Void (1920-1950s): Following the declaration of Republic in 1923, Ankara has been stated as the capital city by the new regime and this settlement was about to face a substantial transformation in political, intellectual and economic contexts as well as in social life and urbanism symbolizing the passage from an unsettled society to a nation (Jausseley, 1929, p.11). The first urban plan by Carl Christoph Lörcher (1924-1925) supported the development in and around the old city center of Ulus (Cengizkan, 2004). However, the need for housing and administrative buildings was crucial and urgent to accommodate both the existing and new coming residents. The pace in the building process created absurd sceneries in daily life during this construction period. By 1932,
Jansen Plan was approved to correspond to the changes in population and altering needs. The main design idea in Herman Jansen's plan was to implement a garden city concept while creating green continuities, main squares and axial alignments for Yenişehir. The development of the Yenişehir adjacent to the south edge of the old city center promised a first planned model of urbanization in Turkey. Yüksel Street is located within this area known as Kizılay today. Yüksel Street was a planned access route for residential areas with a linear microstructure following the public function attained to Yüksel and its surroundings. It was proposed as a free (open) space by Jansen that connects the partial developments in the area concerning street network (Figure 3). The street and its surroundings were proposed as residential areas which are mostly occupied by public servants (Yavuz, 1952).

Yüksel is designed to be a bilateral street providing a twoway directionality in the newly planned areas (Marshall, 
2005, p. 84) (Table I). The street is connected every fifty meters with another route (either as $\mathrm{x}$-junctions or t-junctions) making it continuous and well connected in the plan proposal. However, these functional urban qualities are not seen in the plot layout within the site since there were a few lots developed with a low and scattered frequency. However, towards the 1940s, physical design decisions in Jansen plan became visible in the urban layout. This physical urban development was parallel to the socio-economic dynamics as Kizllay area started to attract commerce. The emerging building setting was composed of detached, two-story singlefamily houses in gardens forming a highly permeable and loose urban fabric. This loose-grained pattern of the newly developing building units and street structure started to improve in the upcoming years with the rapid construction of housing for the public servants (Figure 4). Karaosmanoğlu (1934/1981, p.142, [translated by the author]) depicts the houses of Yenişehir around the 1930s as below:
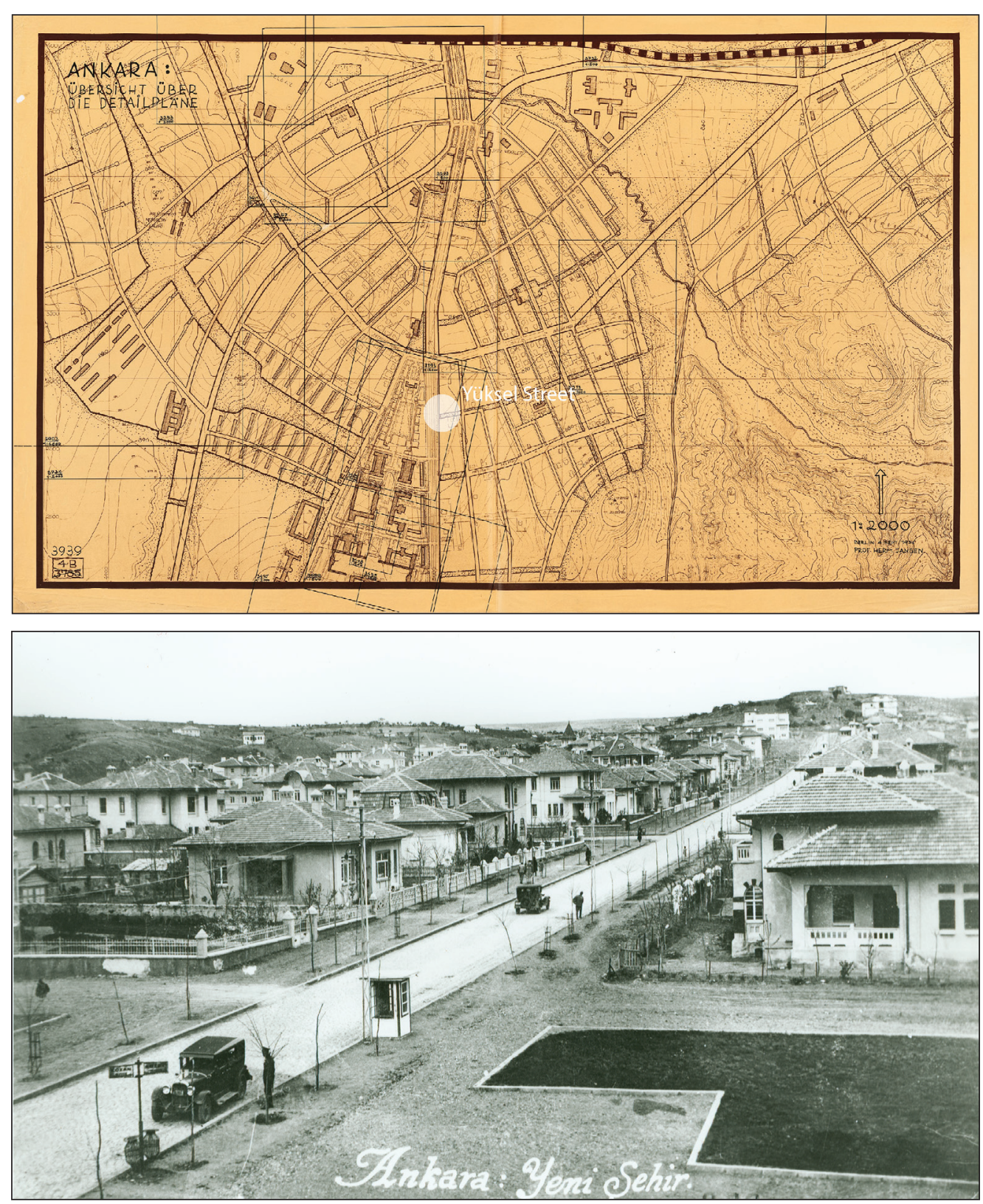

Figure 3. Plan of

Yenişehir, 1932

(1:2000): Yüksel

Street as "free

(open) space" that intersects with the residential streets perpendicular to it. Source: METU Faculty of Architecture Maps and Plans Documentation Unit.

Figure 4. Yenişehir is rising 1926-1930. Source: Koç University VEKAM Archive, Inventory no: 0119. 
Table I. Morphological Analysis of Yüksel Street and Surroundings between the 1920s-1950s

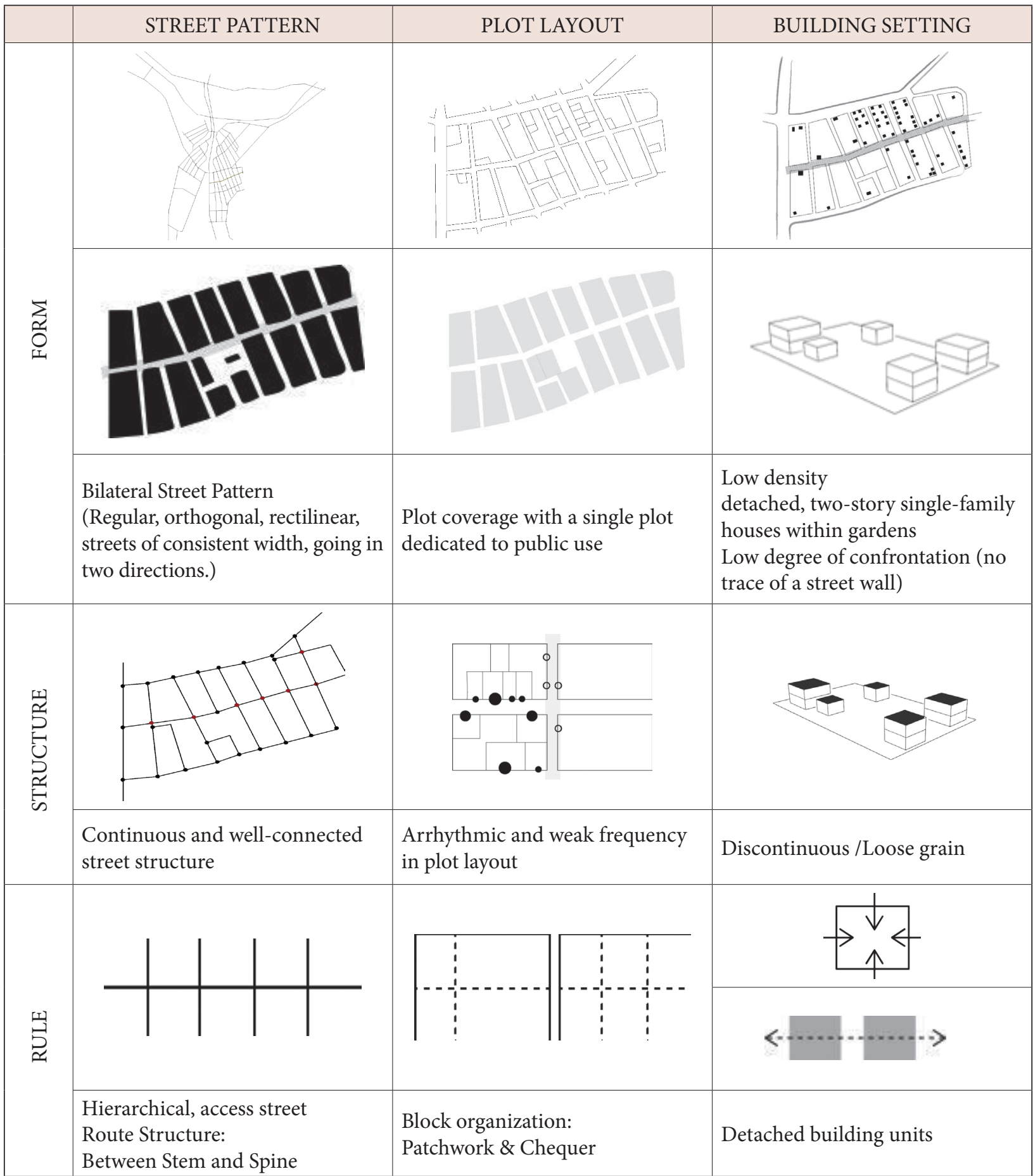

Source: Rendered by the author, 2018.

The study is based on the Jansen Plan (1932) and adapted from the conceptual framework of urban morphological analysis by Çalışkan (2014), and elaborated by the author for the case of Yüksel Street. 
All of the houses in Yenişehir are like the castles of ego and egoism. These houses stand at least 30-40 meters away from each other, and they look like a home of ego more than anything else. It is so visible that no community or neighborhood life exists here. Each family live in their ivory towers. That is what Yenişehir is in eternal silence and desolation with no children playing in the gardens, and no music is heard from the houses; no youth walking around in joy.

Encounters of Old and New (the 1950s- 1980s): The socio-economic and political changes affected the urban characteristics of the city center in Ankara. The post-war politics of the government in the 1950s especially on agriculture resulted in a migration wave from rural to urban areas. Due to the population increase and demographical change, the transformation of the land-uses system became inevitable. Hence the new and old was starting the mold into each other, creating diversity as well as clashes between different social groups (Güneş, 2013; Tanyer, 2006). In the context of everyday life, this went hand in hand with the development of consumerism, western lifestyle and consumption as well as the diffusion of mass communication (Usal, 2014). Various new shops opened along Atatürk Boulevard (Tanyer, 2006, p. 3). The construction of the first skyscraper in 1959 (Emek İşhanı) of the city in Kizılay solidifies this tendency. This building became a significant physical and economic landmark due to its architecture, location, and commercial function. Besides marking the urban and economic context physically, it shows a passage from a low rise and lowdensity residential site with a quiet lifestyle in a more dense, high-rise and dynamic urban environment. Together with the eloquent book of Sevgi Soysal entitled Noontime in Yenişehir [Yenişehir'de Bir Öğle Vakti] (1973), the social encounters and conflicts, as well as the urban change, are being captured in the verses below:
Buket diye bahçeli bir meyhane vardı Yenişehir'de [There was a tavern called "Buket" in the Yenişehir,] Yikıld çoktan GIMA var şimdi yerinde

[Had been demolished long ago, there now stands GIMA] ....

Cahit Ağabey'le otururduk yaz gecelerinde

[I used to sit with Cahit Ağabey during summer nights,]

Ne Cahit kaldı, ne Buket, ne fiskiye

[There are no more Cahit, Buket or water-fountain there.]

The encounters of old and new are also traceable in the street form as the previous housing setting was gradually transforming as well (Figure 5). During the 60s the loose urban plot layout with single-family houses was replaced by four and five-story houses. With the densification of the building setting and the unexpected appropriation by mix-uses, this transformation was diverted from the proposals in the Jansen Plan (Evyapan, 1981). The quiet neighborhood with a homogenous inhabitant group was transformed into a new city center with various functions and a new urban landscape of apartments. In the context of form composition, the intensification enabled a certain regular rhythm and feeling of enclosure within the core access routes including the Yüksel Street and surroundings. Therefore, the street line started to become visible and legible to the inhabitants. These streets were either intersecting or connecting to the main boulevard (Atatürk Boulevard) which is occupied with new uses to the city such as restaurants, cafés and located so close to the main square (Kizılay Square) and the park (Güvenpark) (Batuman, 2006). The center, therefore, started to promote liveliness within the city. Yüksel Street, at this time, was as a passage to the boulevard both by pedestrians and cars; as well as a stop for the emerging central uses.

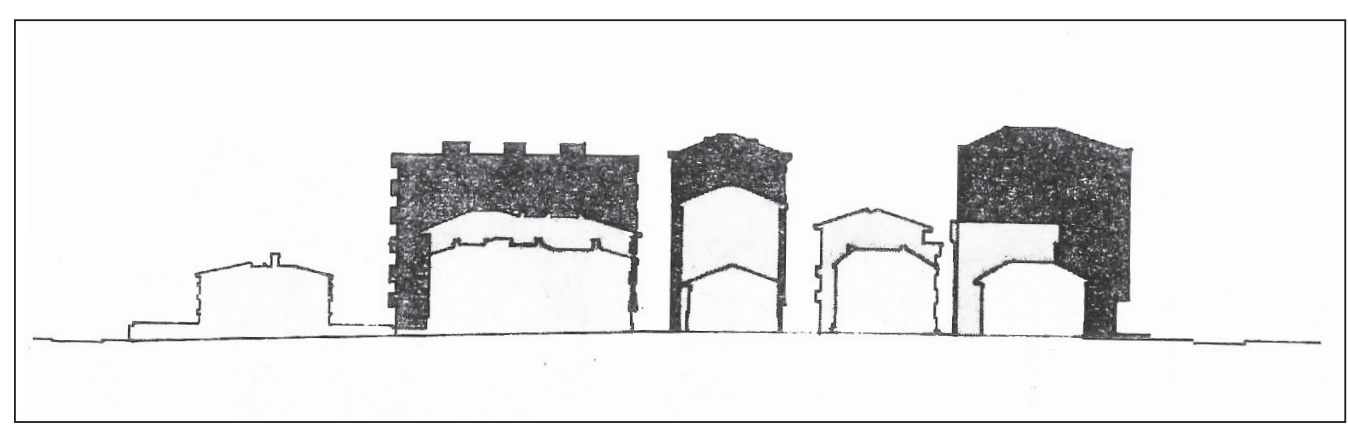

Figure 5. Change of silhouettes in Yüksel Street between 1939-1977. Source: Evyapan, 1981. 
The new city center was mostly occupied by middle and upper-class users in the 60s and 70s (Bayraktar, 2013). Since the public servants were typically residing in and around the site which was accelerated with the opening of the national assembly hall in 1961 within the vicinity. However, the lack of urban service provision by the local government due to the unexpected demographic and economic transformations left the city's urban plans insufficient. Thus, Kizllay was announced as a Central Business District following the Yücel-Uybadin Urban Plan (1957) without a comprehensive approach that integrates pedestrian and vehicular transportation and land-use needs. Moreover, a new law for the property ownership was enacted between the years of 1968-1972 declaring the center as the high-rise region causing substantial physical transformations (Evyapan, 1981). The urban form composition of the site started to alter drastically. The single blocks with two or four floors within gardens were transformed into high-rise buildings still protecting the identical plot size causing densification of the built-up area.

The buildings were increased up to 6-10 stories with a next building order without any preconception for the urban infrastructure problems that this would bring (Bilsel, 1977) (Table II). Besides the alteration in the form and the activity pattern within the built environment, the street started to employ particular political identity by 1950s by becoming a node for the protests by vari- ous political groups (Dinçer, 2016). The opening of the Social Club for Political Sciences Graduates (Mülkiyeliler Birliği) in 1964 at the intersection of Yüksel and Konur Street, and the Union of Chamber of Turkish Engineers and Architects at Konur Street contributed a lot to this wave of critical political environment influencing Yüksel Street to become a site for the street politics (Bayat, 1997; Dinçer, 2016, p. 60). This identity continued to prevail throughout turbulent political events in the country during the 1980s and lasted until today. In the 1980s, the wave of liberalization of the economy and the weakening of the social welfare state in Turkey affected the urbanization agenda, its spatial reflections and everyday social life in cities. The new role of the state as the facilitator rather than the service provider let privatization of public institutions and services, and education were among these. Meanwhile, some inner streets including Yüksel (partially), Konur and Karanfil Streets were pedestrianized in the 1982 (Akıss, 2001). The pedestrian use gave the street a strategic and symbolic public value.

Complexity and Order (the 1980s-2010s): The ease of pedestrian mobility and the secure connection to the public transportation contributed to the urban and social qualities of Yüksel Street, which was an in-between yet eventful public space of urban life during the 80 s and 90 s (Figure 6). These functional urban characteristics aside, the street's cultural, social and political meanings are an

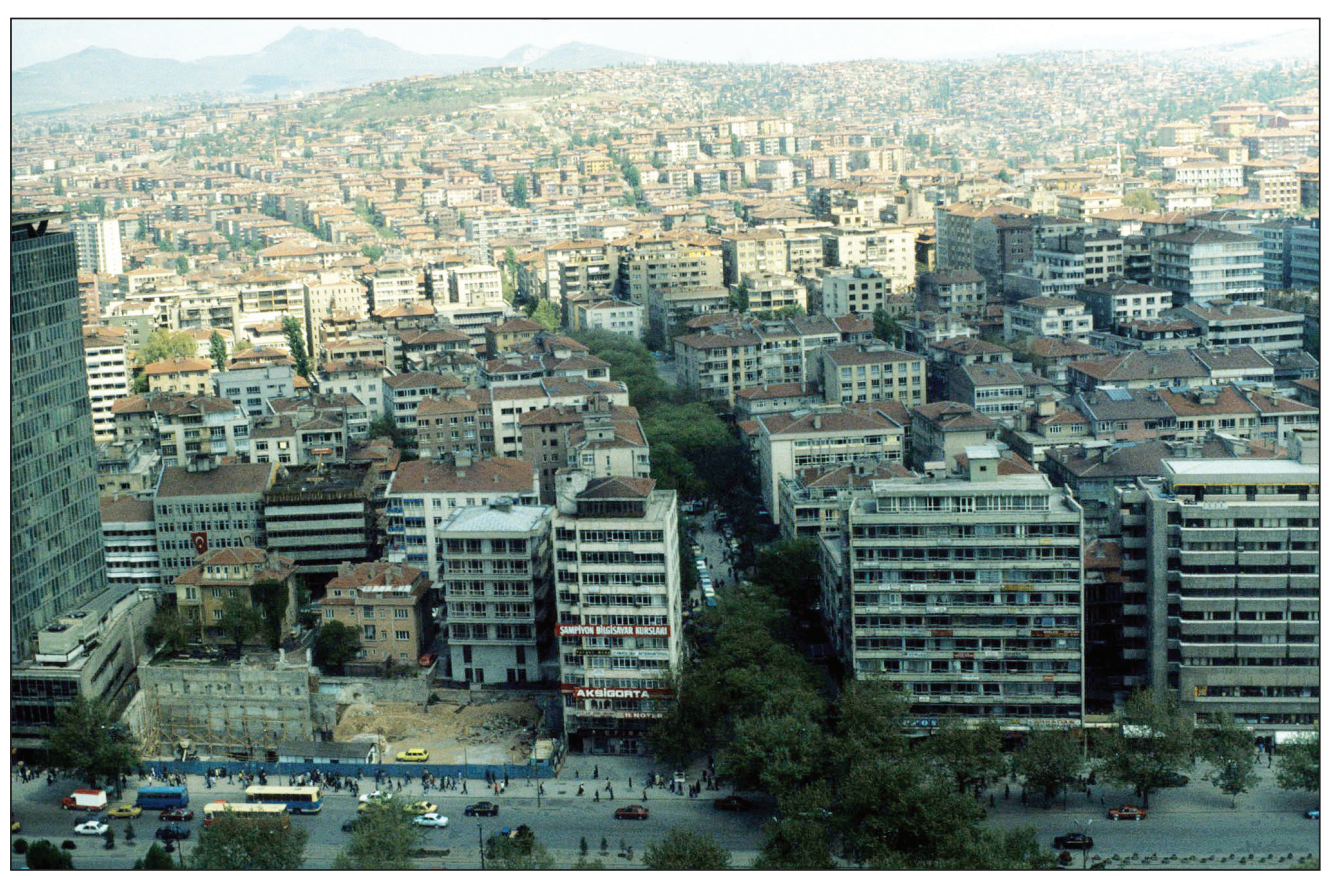

Figure 6. Yüksel Street before pedestrianization, the 1980s.

Source: Baykan Günay Personal Archive. 
D. Cihanger Ribeiro, The Poiesis of Everyday Life and Space in Yüksel Street

Table II. Morphological Analysis of Yüksel Street and Surroundings between the 1950s-1980s

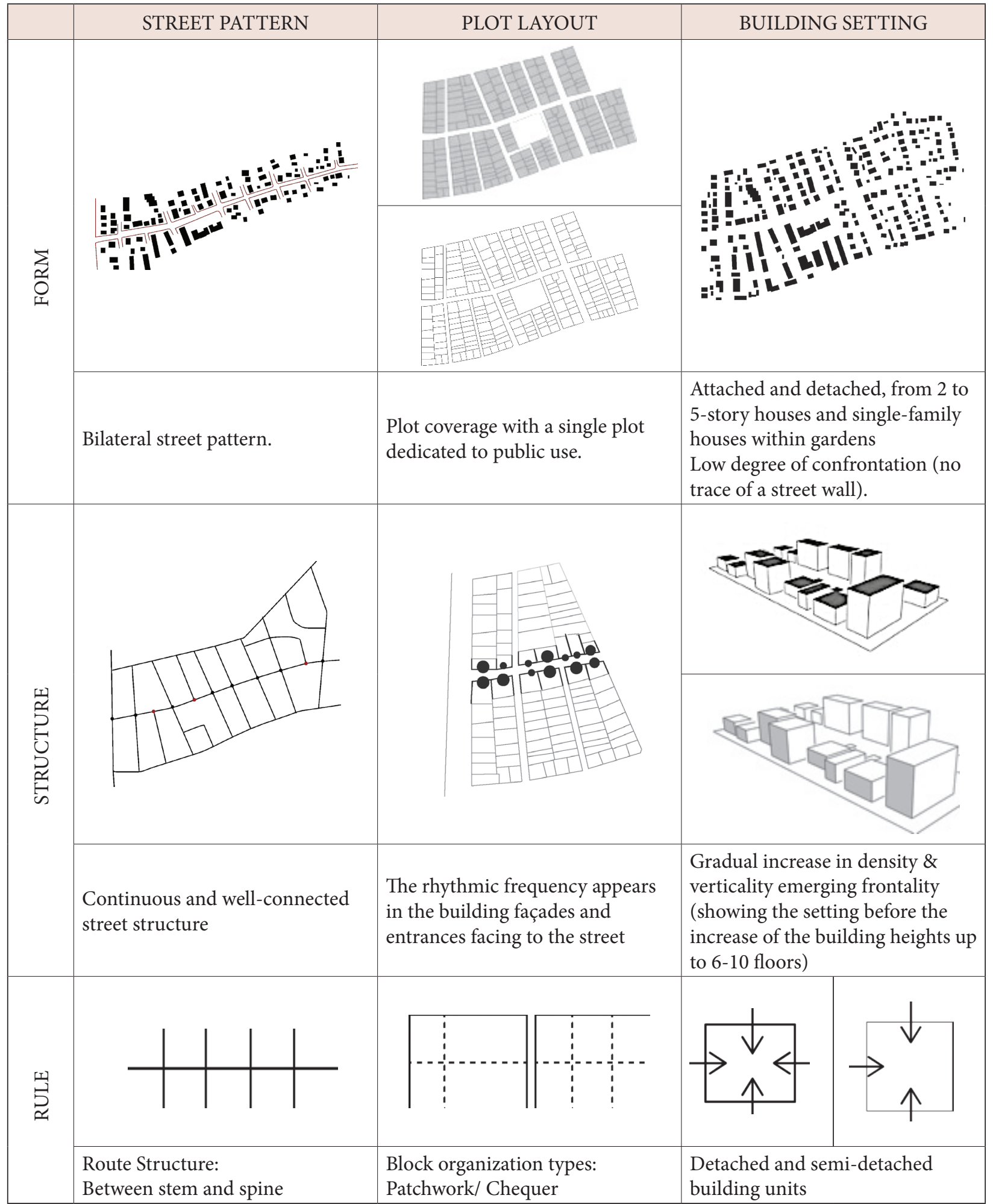

Source: Rendered by Duygu Cihanger Ribeiro, 2018. 
indispensable part of its development. An example is the initiatives of the local municipality for creating a cultural street in Yüksel area through street events such as concerts and exhibitions. The emergent social response to this has been the increase in the street musicians in Yüksel Street. A documentary from 2016 called Black, Not Grey: Ankara Rocks by Ufuk Önen covers the rock music sceneries of Ankara in the 80s and 90s, and an interviewee claims "As an Ankara musician, I believe that center of the world is Yüksel Street." Besides music, the placement of bronze sculptors along Yüksel such as the waiting man, shoepolisher, a woman on the bench is placed in the street. Still, the most known and significant one is Human Rights Sculpture was sculpted by Metin Yurdanur and placed at the intersection of Yüksel and Konur Streets in 1990. This monument has become a social and political node for meetings and various gatherings. Back in the time, the Yüksel youth was a significant social group worth mentioning. Composed of mostly high school students or teenagers hanging out in the street, Yüksel Youth was studied as a sub-culture by İsmail Doğan in 1994 for their choice of clothing and entertainment habits. Moreover, street politics evolved with the public demonstrations usually occupying the intersection between Konur and Yüksel streets covering the human rights monument and Mülkiyeliler Union area.

From 2000 onwards, Yüksel maintained its functional, commercial, political and public characteristics in different balances. Today, the significant nodes within the street are: Human Rights Sculpture (political gathering, meeting point); Mülkiyeliler Building (core of political discussion in the past, still has a symbolic and spatial attraction), Dost Bookshop is located in Karanfil Street near to Yüksel Entrance (its entrance is known for meetings), and the last one is the Mimar Kemal School (historical and architectural significance). Besides the socio-spatial changes, the form characteristics did not alter much in the street regarding the street layout and building settings. Still, the higher confrontation levels of the building frontages create a street wall and hence enrich the perceptual morphology of the street (Table III). The main characteristics concerning the physical setting have been the user interventions such as the street vending activities (Özcan, 2016), kiosks, night bazaars, overflowing to the street fronts by shops and restaurants. Therefore, this material condition of the street exceeds an analysis of urban morphology and bring the question of user interventions, habitation, temporality, and spontaneity in urban space. The latest urban design is implemented in 2010 by Çankaya Municipality in Yüksel Street to overcome the problems including pedestrian circulation, pavement, lighting, safety, and expansion of informal developments, social difficulties and alike. These issues are tried to be solved through physical rehabilitation and legal measures for the removal of informal counters from the entrances and front yards of some buildings. After the project was implemented, the former uses started to appear again.

Two recent political events worth to mention for the formation of everyday life and space in the street. The first one was the protests occurred at the end of June 2013 following the Gezi Protests started in İstanbul. The Kizllay junction and the surrounding avenues and streets were used for demonstrations by the protestors. The main boulevard was closed for vehicular traffic and the roads intersecting the boulevard were occupied by the protestors by blocking the entrances with barricades. Yüksel Street, along with Konur and Karanfil streets was used mostly for resting, hiding and medical treatment while the Metro exit of Yüksel was highly exposed to the gas bombs and conflicts between the protestors and the police. The second example is from November 2016. After a sole protestor's press statement against the detention from public service, the protest accelerated and resulted in a hunger strike that is followed by other supporters who occupied the human rights sculpture as their resistance area. In 2017, after the police intervention, a temporary police station is placed behind the monument, and the monument itself was surrounded by police barricades to prevent any more gatherings in the area. From these recent examples of the role of Yüksel in the continuum of street politics in Ankara to the mixture of land use and diversity of users, the street has an everchanging everyday life and spatiality. The archive section has unfolded the short but complex urban setting history of Yüksel Street. This section sheds light on the social and spatial development steps of this important urban street which is usually explained briefly in the related studies. The interplay between the morphological qualities and the social setting of the street presents the dialectical link between the tangible form of urban space and its intangible forces as social groups, economic and political influences. 
D. Cihanger Ribeiro, The Poiesis of Everyday Life and Space in Yüksel Street

Table III. Morphological Analysis of Yüksel Street and Surroundings between the 1980s-2010s

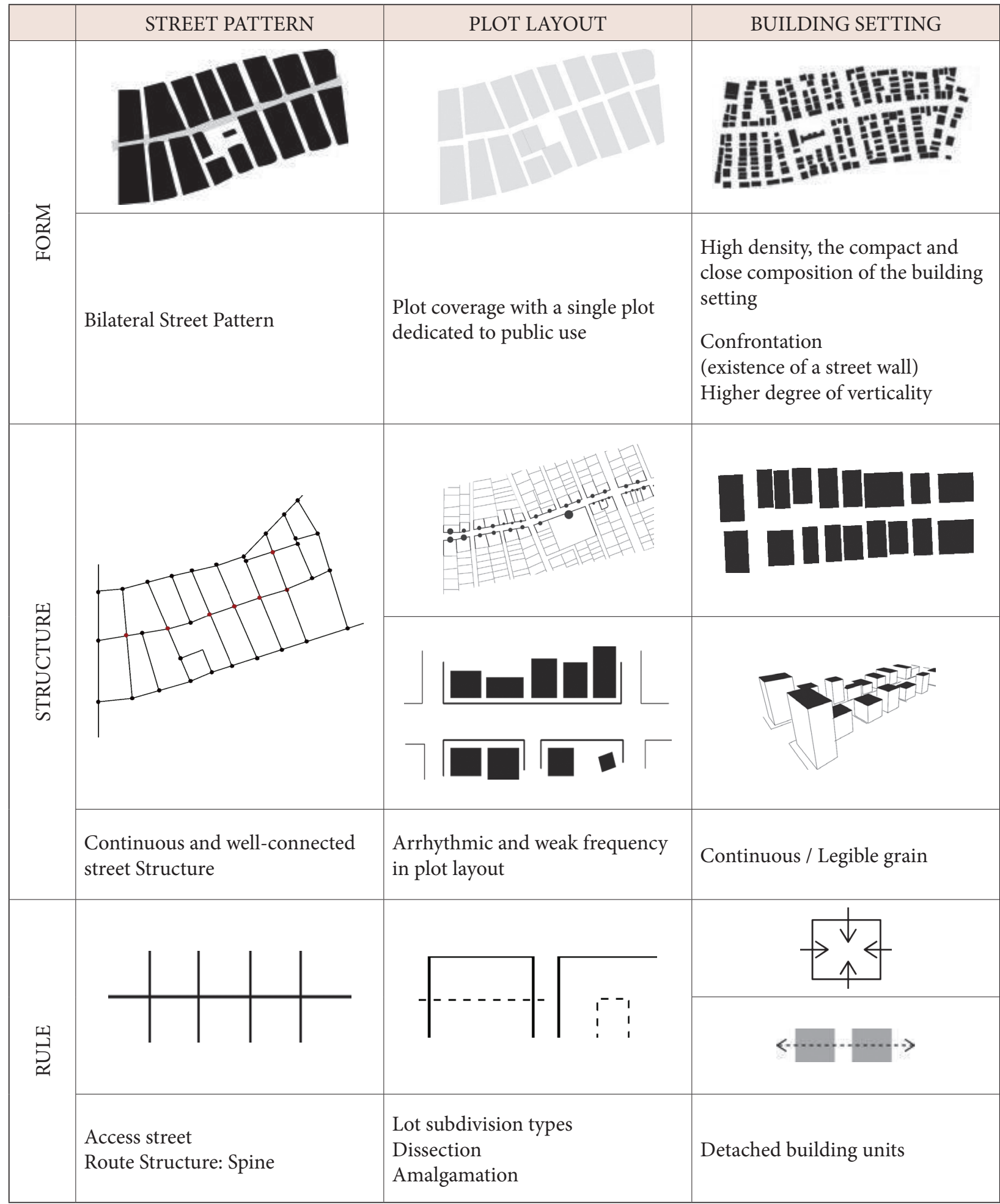

Source: Rendered by Duygu Cihanger Ribeiro, 2018. 


\section{Memory Enacted in the Present}

Today, everyday life in Yüksel Street carries both the mechanical processes of modernity such as peak hours, timetable of mass transportation, division of working hours, and inventiveness of the users as in the case of social gatherings, individuals' time out activities, and political protests. There are many shop signs, personalized store-fronts, counters selling many things flowing to the walkway, people distributing flyers or trying to make questionnaires, countless of pedestrians walking in different rhythms as well as the ones who are sitting on the benches or strolling around the shops. In the context of these examples, the everydayness is mostly related to the sociology scholarship. However, these daily practices and events have spatial reverberations as well. From the perspective of urban studies, the physical interventions by users that differ from those intended by planner are important to grasp the social dimension of space. The role of users brings the dimensions of temporal and human expressions to the discussion. Therefore, the field study was engaged with the alternating urban temporality, change, and multiplicity of actors besides the focus on the spatial qualities. This asks for an ability "to live with more than one spatial and temporal sense of a local place - a 'here' as well as a 'there', and a 'then' as well as a 'now' the ability to live with combinations of what is familiar or what is local." (Hall, 2012, p. 6) This dialectical perspective to embrace "spatial and temporal sense of a local place" is a demanding process for documentation of everyday life and its space in Yüksel Street. Since the primary concern is to understand the making and creating of urban space and life, the questionnaires and surveys would not satisfy this research (Augoyard, 2007). Data is collected from a pedestrian point of view, taking pictures, walking, making pauses to draw or merely observing during the initial field visits to Yüksel Street. In October 2016 an initial visit has been paid to the street, and its visual data helps to attain the changes in some of the uses. However, the longitudinal observations and visits to the site cover the dates between March 2017 and March 2018. This site visits not only provided the visual data that is composed of over 550 photographs and on-site drawings and field notes, but also it provided a more insightful perspective towards the street. The data has been gathered through a photographic survey, field-notes, on-site drawing, video recordings and unstructured talks with users. The data will be analyzed under practices and aesthetics. For practices, the rhythmanalysis examines the social and spatial practices showing the living temporalities on the street by using the empirical data. This analysis leads to a discussion on the emergent urban design qualities and a final evaluation of urban visual aesthetics and its possible encounters and clashes with everyday life.

\section{A Sketch of Rhythmanalysis}

Various urban activities and spatial forms have a temporal dimension and living rhythms contributing to the composition of space. Urban rhythm has social and spatial reverberations (Wunderlich, 2013) and as a musical piece, it has different qualities which sometimes create harmony or discordance. In the context of everyday life and space, these urban rhythms are not only audial but visual as well as reminding the transformations and continuities in a socio-spatial setting. Rhythmanalysis as an approach to attaining the temporal dimension of social space has been coined by Lefebvre (1992/2004). However, this work does not provide a method or a specific structure for analysis but draws a framework on the dialectical relation between mechanic and lived temporality. The analytical approach to practices and aesthetics through a sketch of rhythmanalysis unfolds the findings of the empirical observations of everyday life and space in Yüksel Street. The two main categories of practices and aesthetics present how the memory of space is being enacted. Still, the former covers the everyday social practices such as events or activities of people; while the latter includes a discussion on the emergent aesthetics of physical interventions by users to the built environment.

To grasp everyday urban rhythm demands attentive and sensitive "eyes, ears, ahead, and a memory and a heart." (Lefebvre, 1992/2004, p.36). In this sense, the study simplifies the units of rhythmanalysis as set by Lefevbre. Therefore, instead of directly following the dialectical rhythms of eurhythmia, polyrhythmia, and arrhythmia as stated by Lefebvre, there are three terms to reflect better the spatial characteristics of rhythms and these are: constant rhythms, transient rhythms, and ruptures. Lefebvre (1992/2004) describes eurhythmia as the united rhythms and sign of health, polyrhythmia as the conflicting yet co-existing rhythms in space and finally arrhythmia as the discordance of rhythms, disturbance. Following the similar logic, the rhythmic units of analysis of this study evaluated the site-specific findings of daily 
observations in Yüksel Street. Hence, the constant rhythms are continuous and dominant social practices (pedestrian movement, murmurs), the transient rhythms refer to the social practices conflicting the premeditated uses in space yet still co-exist with the ongoing activities (stopping, waiting, time-out activities by individuals or small groups); and finally ruptures explains the changing and unanticipated uses of space (appropriation of space, informality, protests).

Practices-Social Setting and Lived Temporality: In Yüksel Street, life starts in the early hours of the morning. The street is open to traffic until nine o 'clock in the mornings due to the service provision to the shops and restaurants. In these early hours, there are also the open cafes serving tea and breakfast as well as the municipality workers collecting the garbage and cleaning the street.
Towards noon, the silence leaves its place to a dynamic and ever-flowing urban life. The Metro exit and its close surroundings become a significant node with pedestrian movement, time-out activities such as sitting or waiting and exhibits an example of the interaction between public life and built urban setting (Figure 7). The walls surrounding the Metro exit is used beyond its intentional design and harbors several social activities such as sitting, eating, meeting and observing. Another essential component of daily street life is the street vendors in Yüksel Street. Their locations are somewhat permanent despite the temporality of their job and belongings to sell. Their existence and use of space especially highlight the potential in urban space and contribute to the vibrancy of urban rhythms. This has been followed in the field notes taken in March 2017 as follows:

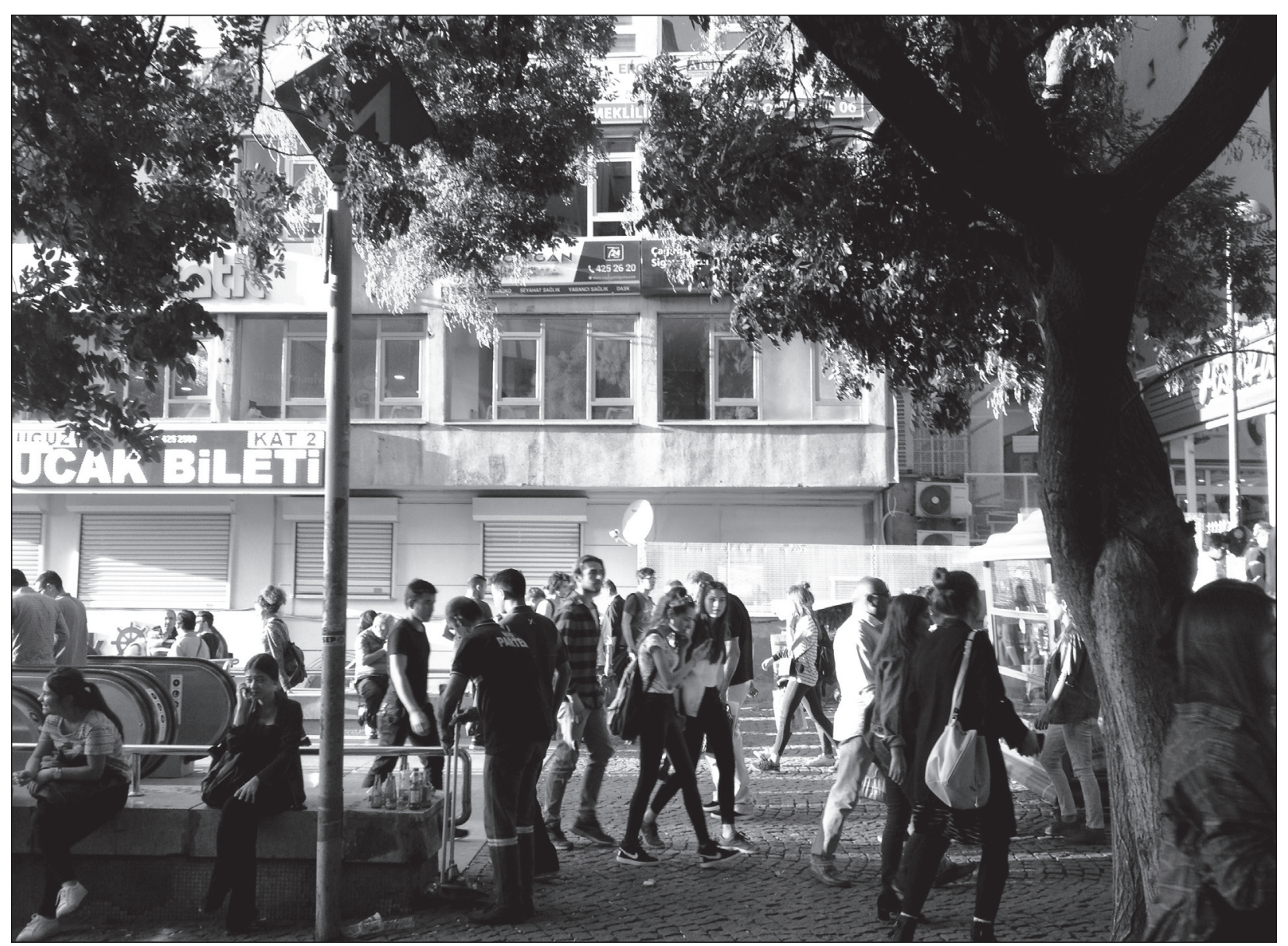

Figure 7. Constant rhythms. Pedestrians in the street in a rush hour around 18.00. Photograph by: Duygu Cihanger Ribeiro, May 2017. 
A simit seller, a shoepolisher, a vendor selling numerous products from lighter to combs... They all greet the people as they step on the street from the boulevard, or as they ascend with the escalator from the metro exit. I am facing the simit seller; he seems to know so many people. The people sometimes pause and talk with him. However, I cannot hear anything; they might as well be just asking some addresses. Because the seller occupies a strategic location. He and his cart stay just in the middle of the broad stairs after the metro exit, as a humble landmark, with an aim to earn money by selling the cheapest street food, a cushion right under his knees that he took advantage of the height of the stairs and used it as a seat...

(Field notes, March 2017)
The users and activities initially reveal the constant rhythms in the street which are the continuous and subtle events and actions. They compose a unity of rhythms and almost a harmony peculiar to the Yüksel Street through the continuity of movement and murmurs of pedestrians underneath the seeming disorder. This vividness is due to the increase of the visitors from day to night, and of neverending traffic flow near the street causing a continuous flow of pedestrians into the pedestrianized street. These more or less predictable and habitual rhythms merge with the unexpected or transforming social practices that are called transient rhythms. These rhythms are created by individuals and small groups as they interact with the built environment in different forms and temporalities (Figure 8). In Yüksel Street, the continuous flow of the crowd is disrupted by individuals when they wait, rest

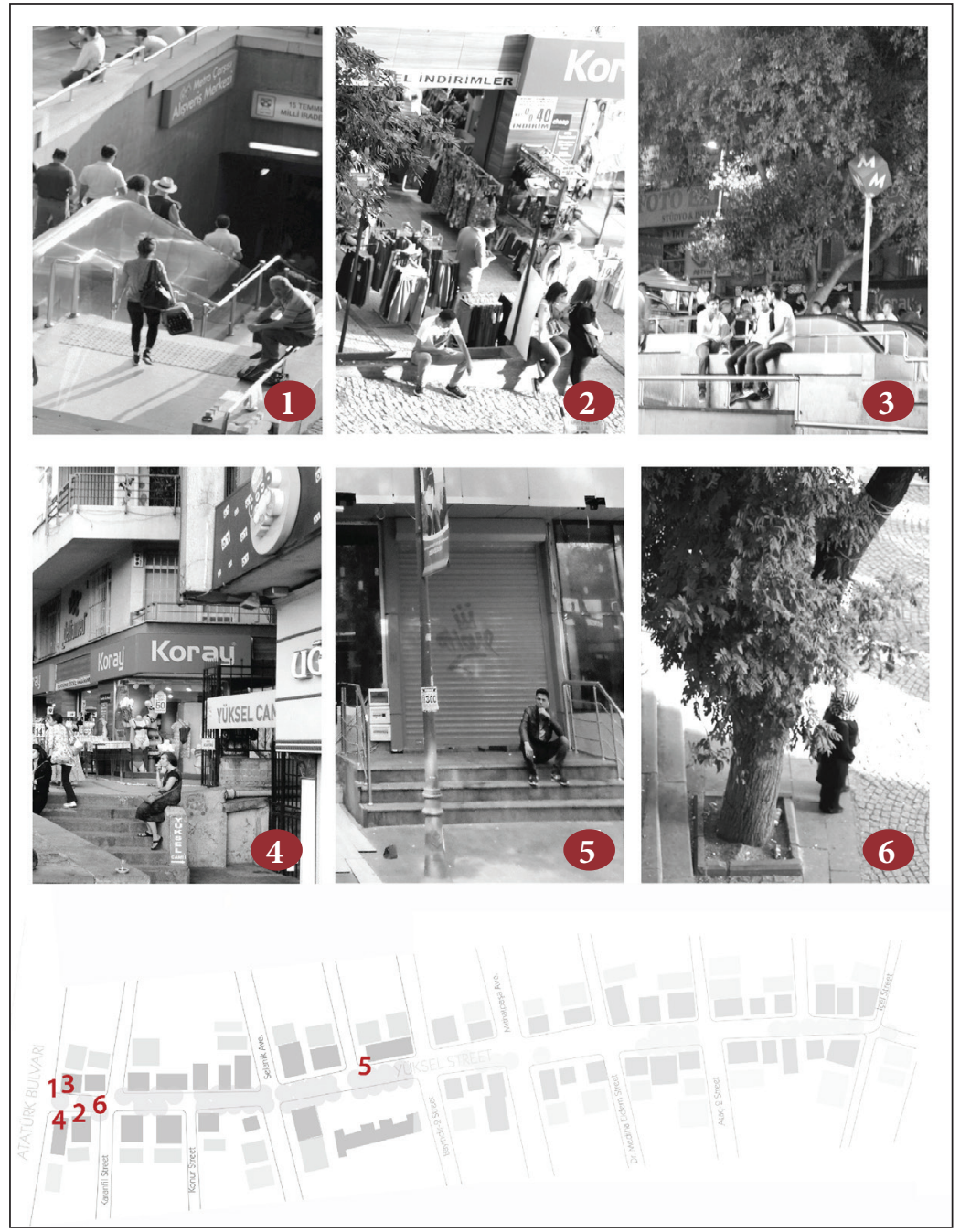

Figure 8. Transient rhythms: the relationship between the individuals and physical setting. Source: Duygu Cihanger Ribeiro. 
D. Cihanger Ribeiro, The Poiesis of Everyday Life and Space in Yüksel Street

or play with their phone; and by small groups of people when they cluster (Figure 9A and 9B). By still making use of the existing physical urban setting, people change the continuous rhythms for a limited time and generate new spaces of sociability. The transient rhythms and the resulting spatial relations are the deviations from

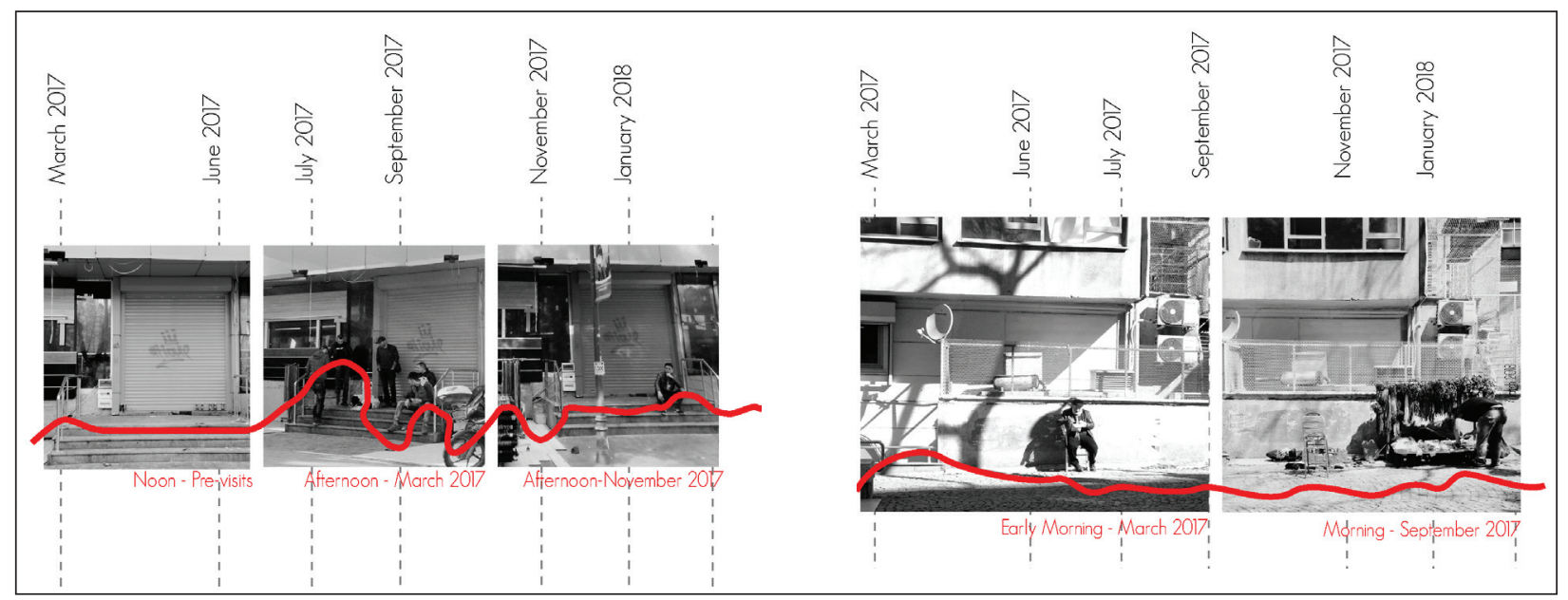

Figure 9A. Some example of transient rhythms occurring through alternating social use (The red line abstracts this rhythmic change, the darker red circles represent the location of examples).

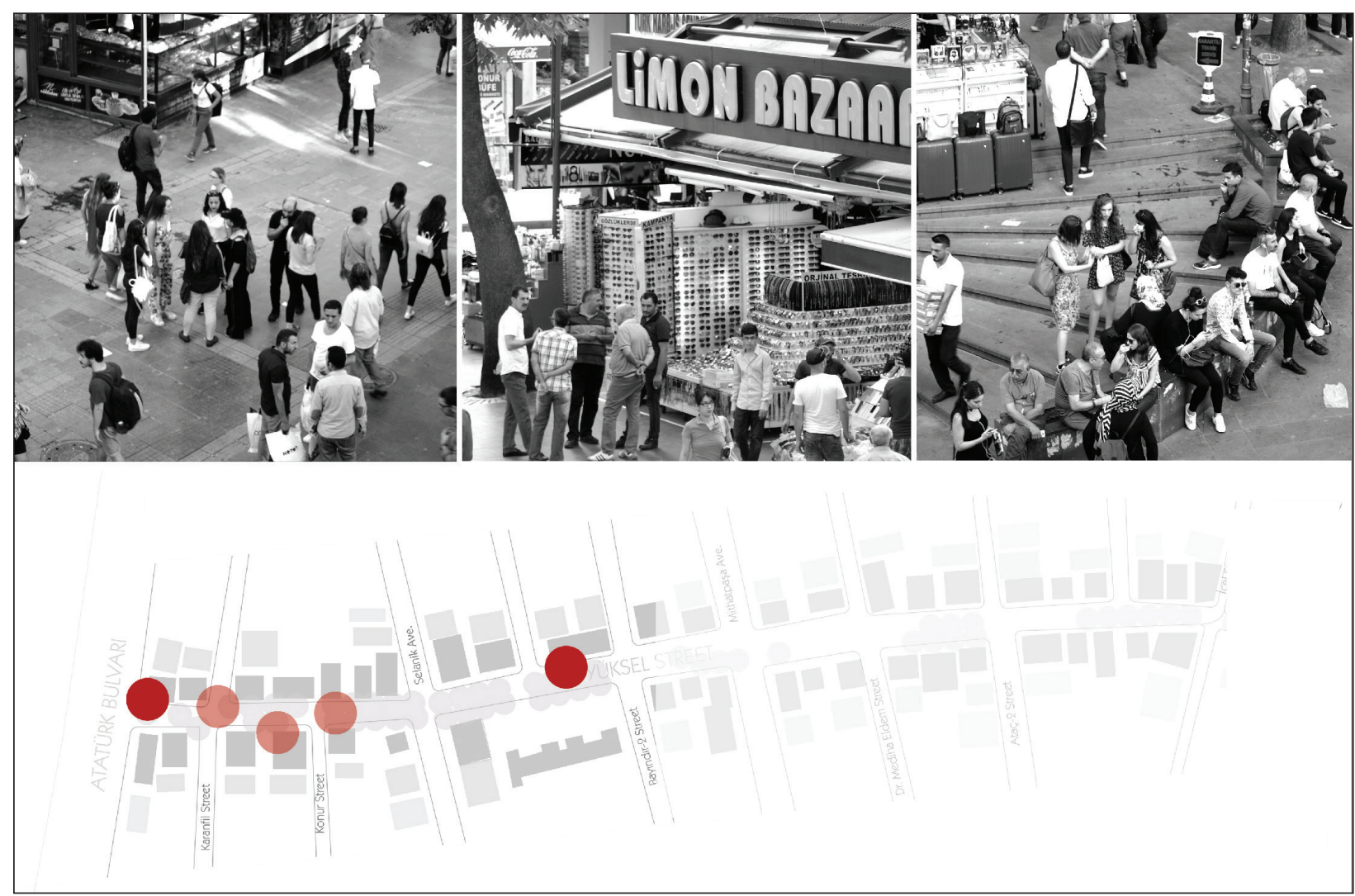

Figure 9B. Groupings along the street (Represented with lighter red circles on the map below). Transient rhythms: Unexpected yet integrated social uses of space.

Source for Figures 9A, 9B: Duygu Cihanger Ribeiro Personal Archive, 2017; Elaborated by Duygu Cihanger Ribeiro. 
the continuous movements and events yet still co-exist with the constant flow in the area. However, not all the rhythms are subtle, but they are still a part of everyday life in Yüksel Street. In some cases, the breaking of a continuous rhythm results in a rupture in terms of space and its practices as in the case of the protests around the human rights sculpture or night bazaar (Figure 10A, and 10B). From a theoretical perspective, the ruptures

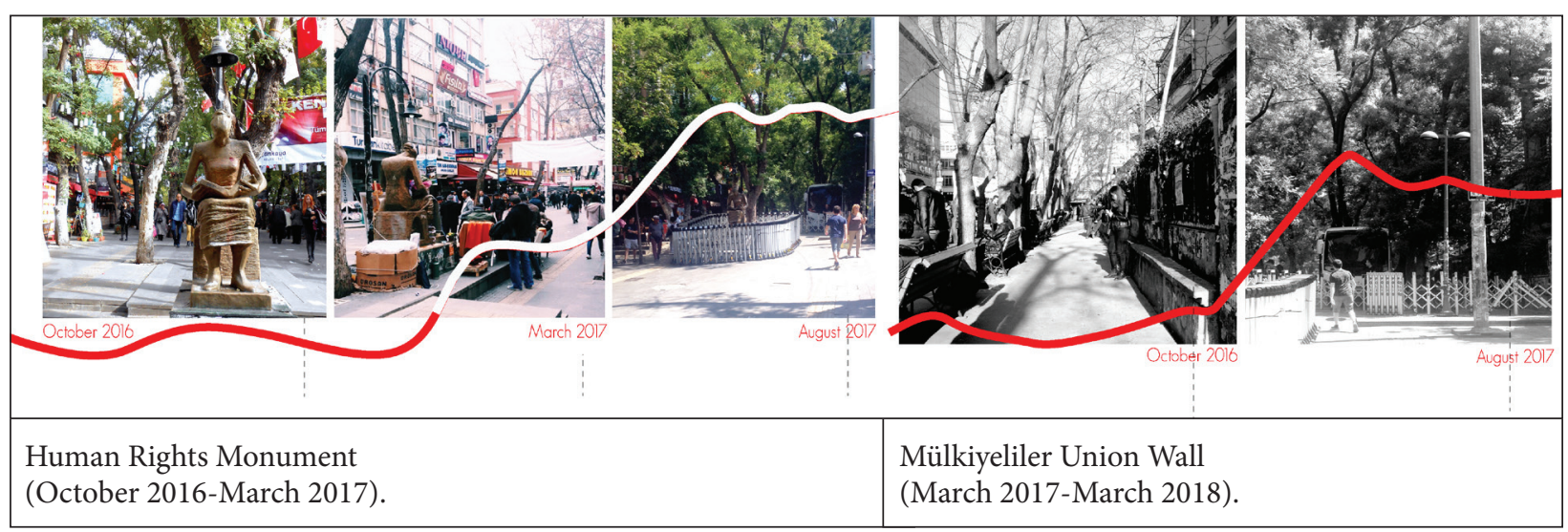

Figure 10A. The red line abstracts the rhythmic change, in this case, a rupture, the red circles on the map below indicates the location of monument.

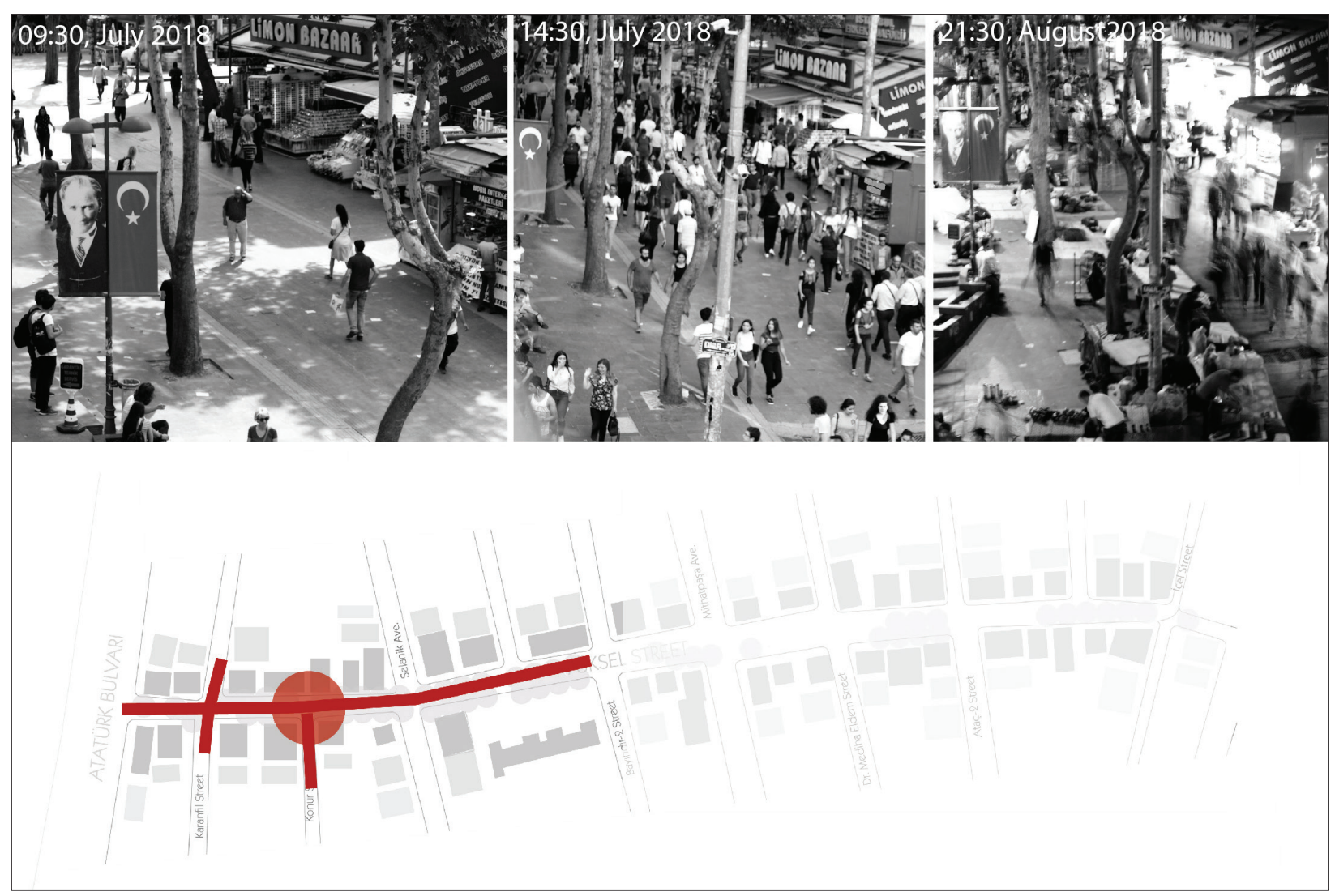

Figure 10B. Ruptures in space and practices.

Source for Figures 10A and 10B: Duygu Cihanger Ribeiro Archive, 2017; Elaborated by DuyguCihanger Ribeiro. 
show the exceptional episodes recorded in the fieldwork and constitute the extraordinary dimension of everyday life (Jones, 2018). Still, these episodes are rather social and temporal bringing the question of their validity for tangible traces on urban form.

\section{Aesthetics-the Everyday Spaces and Ordinary Designs:} The daily social practices and human use sometimes leave permanent spatial imprints in urban space beside composing the urban temporality. In this context, aesthetics refers to the emerging spatial qualities in everyday life and the creation of ordinary spaces through physical interventions of users overlaying the planned urban layout. The examples are various such as overflowing to the street setback to gain more display space in the case of restaurant or shops, appropriating street corners to sell flowers and lottery tickets. These examples are the tangible spatial interventions that were not foreseen or supported by the original blueprint yet still appeared through everyday needs and motivations of people. As they are not foreseen by an urban planner or designer perspective, their emergent nature brings a confrontation to the idea of urban aesthetics. Although they were not subjected to a legal or intentional design process, the ordinary space observed and recorded in Yüksel Street seems to enrich urban life and bring a particular spatial appearance. Beyond visual confrontations between the designed and lived spaces, the emergent spaces influence the physical and perceptual morphology of the site as well:
I notice that if I have studied the street from a base map, I would not see or ignore these sleazily made connections between the buildings. They are not detached-houses anymore; they have been closed, blocked or controlled by gates, fire exits, depots. Not to mention how a familiar urban setting unfolds itself with all of these commercial uses overflown to the street, presenting the occupation of the physical public space, but re-creating it and giving it life and sociability at the same time.

(Field Notes, March 2017)

The physical interferences by users such as adding fire exits, storage units or gates between the detached houses along Yüksel, alter the visual and physical morphology of the street in some cases. After these additions, the buildings form a continuous street wall constituting a set of attached buildings and create a new sense of design quality in space. From a form-oriented perspective, the connection with the other pedestrian streets such as Konur and Karanfil increases the connectivity and visibility at the junctions. This might be the reason for some street vendors as lottery sellers and florists to occupy these corners (Figure 11). Moreover the building setbacks, despite not being planned for that, acts as a flexible and open urban space that could embody various activities from extension of one's commercial territory to provision of interfaces for people to hang around, and wait for meeting with their friends. All of these details

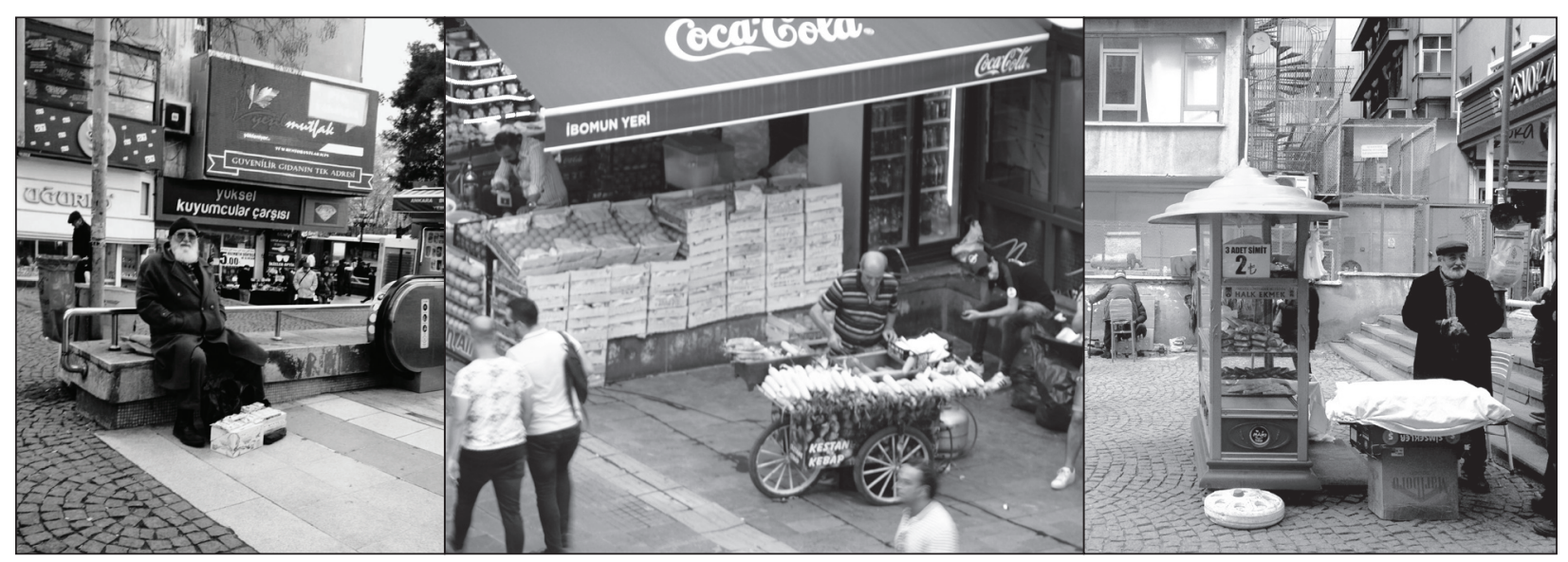

Figure 11. Street vendors as the crucial user group of Yüksel Street.

Photograph by: Duygu Cihanger Ribeiro. 
point out an opening for the flexible urban design studies from a social perspective that learns from the actual and existing human uses of space instead of merely focusing on the physical coding and pre-decided aesthetic concerns in urban design.

There are three main sections along the street that this aesthetics of users' space is revealed (Figure 12). The first section is the pedestrian zone of Yüksel starting from the Metro exit and continues until Mimar Kemal Primary School or Selanik Road. In this section, there are several kiosks and street vending activities together with the numerous signboards covering the facades of the buildings, the tables, and counters occupying the street fronts (Figure 13):

Kiosks almost completely covered the entrance of Yüksel Street from Atatürk Boulevard direction. One in the middle of the large sidewalk of the boulevard, one at the opposite of that, adjacent to the metro exit, and one more just on the corner of the exit; they seem ugly, out of the plan, unfitting. These and many more and usually negative thoughts pass from my mind regarding how they look. It takes a few minutes of sitting and facing this group of kiosks to grasp their touch at the entrance of the street. Physically, they are creating almost a labyrinth, which suprises and confuses the pedestrian. They are breaking the simple routine of a regular sidewalk. To understand what they mean socially, I take more time observing. Then I see the continuous flow of customers to each of them buying small goods, asking addresses. Their blind corners may seem like a shield for some people that wait or simply talk on their phone. Probably, they feel safer like that than being among the crowd. Could I say beautiful to their existence, surely not; but they were beautifully organized in their scope, and they fit the lived realities of the city.

(Field Notes, March 2017)

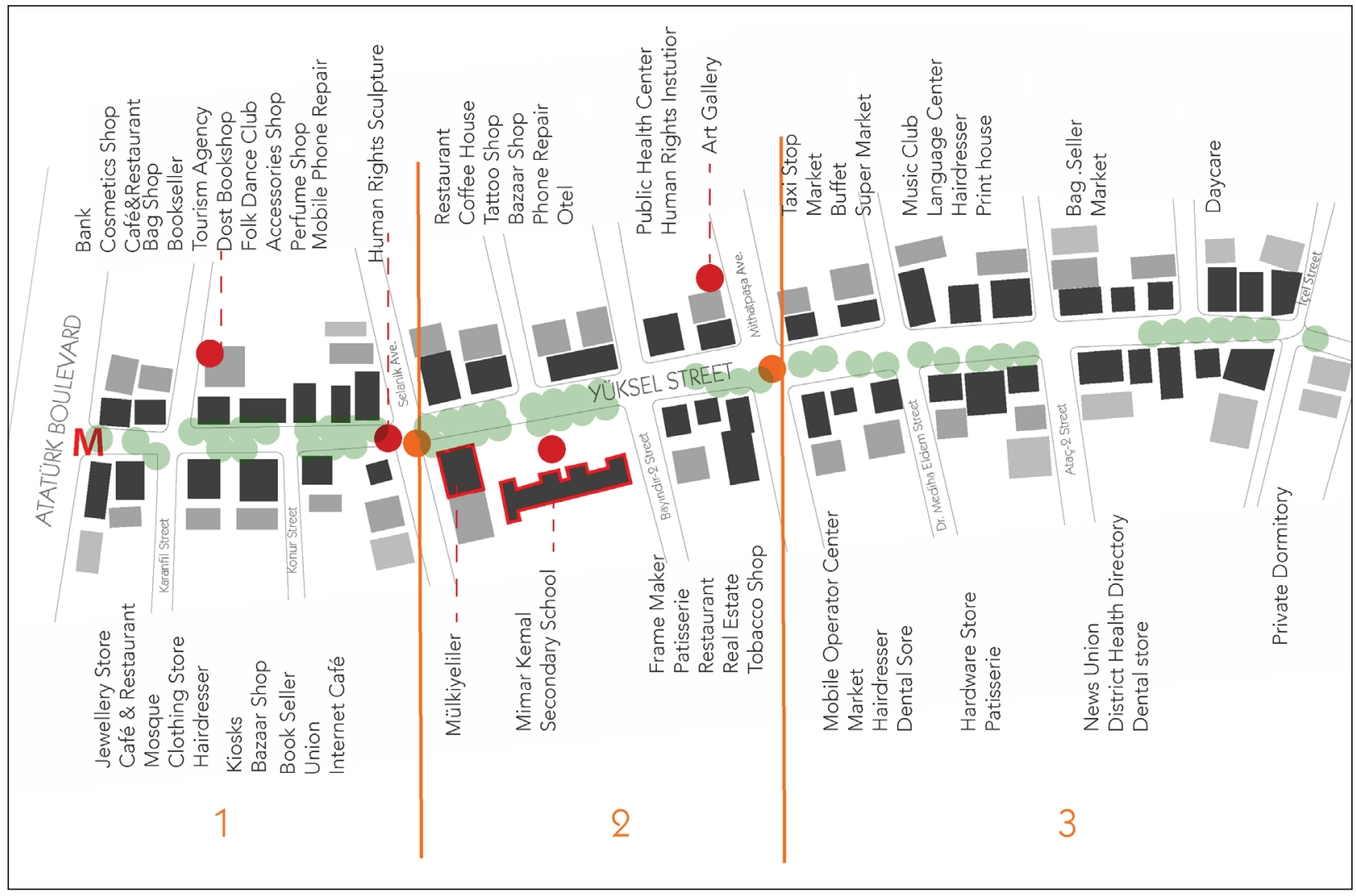

Figure 12. The three main sections along the street and clues for landuse. Source: Rendered by Duygu Cihanger Ribeiro, 2017. 
The second section starts from the Mimar Kemal Primary School and continues until Mithatpaşa Avenue. Here, there are many people sitting on the benches or garden walls of the buildings while some other wait in the street corners to meet their friends or to give a short break of smoking and checking their phone. Besides, there are street vending activities such as florists and a lottery seller in the street corners. From the avenue till the overpass at the end of Yüksel, there is instead a quiet and humble use of the public space referred to as the third section. Mostly the gardens of houses and the entrances are transformed by the inhabitants through the organization of gardens, placing chairs and personalizing some of the balconies. The harmonious everyday aesthetic lies in the refined uses of the interfaces between public and private spheres. The placing of chairs, tables, plant pots in the entrances of the buildings and some examples, personalization of the gardens in a somewhat unusual manner reflect the remaking of urban space through ordinary designs. There are direct interventions on everyday aesthetics through the wall writings and drawings (Figure 14, 15).

The use of several signboards, arbitrary selection of kiosk places, the random appearance of street vendors challenges a discussion of urban aesthetics and design. The everyday life and ordinary spaces should not be categorized with the pre-set scales of professional design interventions since the urban processes are different in the formation of lived space than the production of conceived space. The tangible imprints of urban activities and behavior settings of social life (Barker, 1968) reflect the particular everyday life and space of Yüksel Street. Adding on or subtracting from the planned layout of the street, they are the subtle indicators of poiesis of everyday urban space. Therefore, the physical interventions by users reflect a plurality and diversity in terms of urban aesthetics as they include individual choices in mostly negligible spatial scales. While studying everyday life, these cases are not neglected and presented as the spatial design operations (overflowing to the street setback, holding street corner) or elements (text, images, objects). The discontinuity or repetition of these spatial imprints of lived space gives clues about the expectancies of the users from their urban space. Therefore, the emergent aesthetics due to user interference shows how everyday life research unveils the production of urban space prior to the categorical judgments. The empirical observations

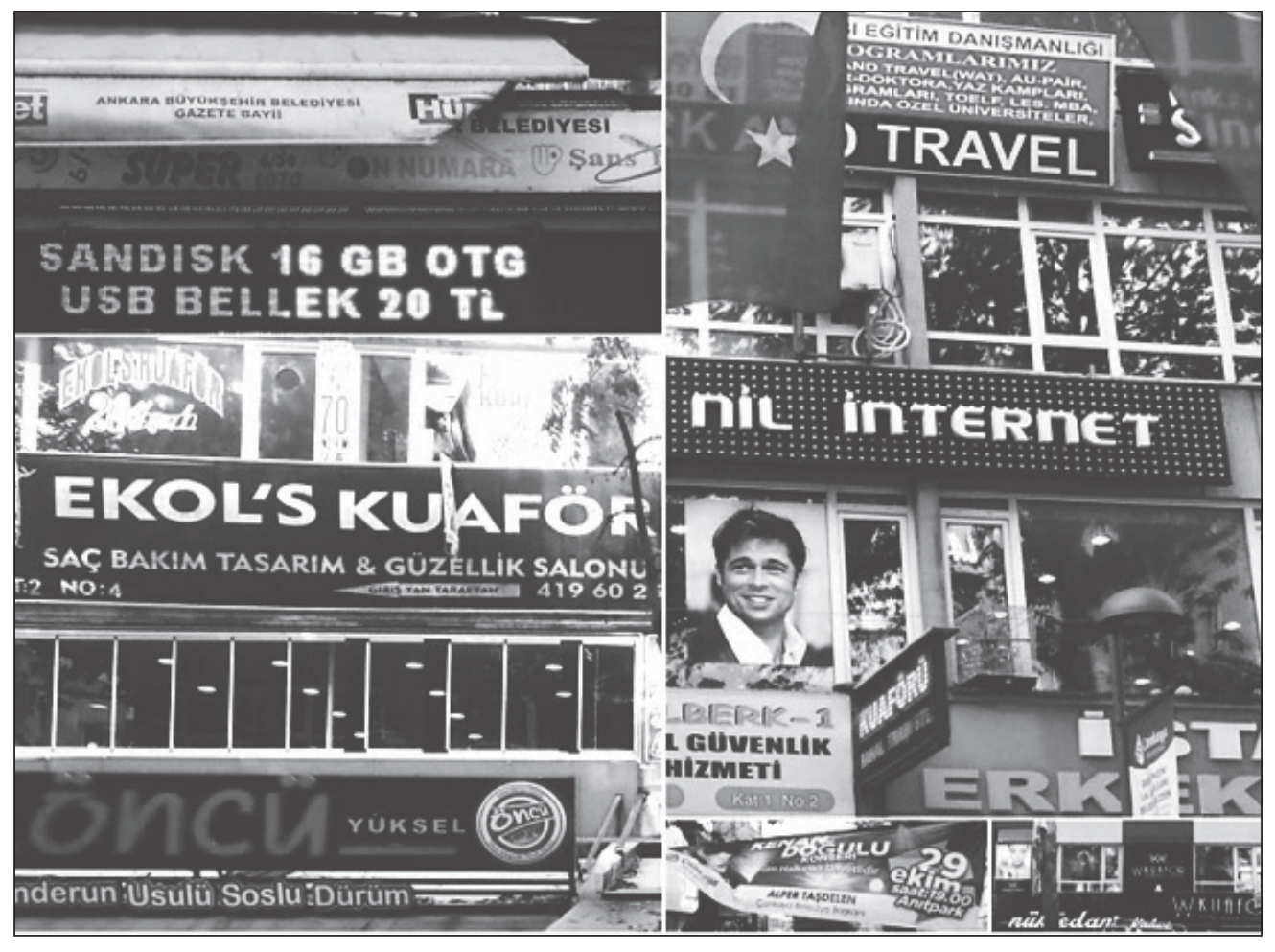

Figure 13. A Collage of signboards from multiple buildings. Photograph by: Duygu Cihanger Ribeiro. 
unfold the aesthetics' of everyday life and space which is messy, unexpected, ever-changing and multifaceted. The places people chose to transform or socialize enrich the ethnographies of Yüksel as they overlay the planned layout and emphasize human influence in space.

\section{Conclusion}

Lefebvre asserts that everyday life embodies the possibility of its own transformation (Highmore, 2002). The poiesis of everyday life and space comes to infiltrate the urban planning and design discourse claiming a transform from within as well. This transformation, I argue, needs to be in the sense of theory and methods of studying urban public space. Although, intervention by users to a designed urban layout brings along controversial discussions on the urban politics, management, design aesthetics; it also underlines the tangible traces of connecting social and spatial processes in urban space. In this sense, the poiesis of every day presents the possibilities of theorizing and empirically research the dialectics of social life and planned urban layouts. The deconstruction of some sociologically rooted terms such as lived space and everydayness from an urban design perspective contributes to the development of urban social theory. Especially, stating that lived space is more than the symbolic uses or counter space and carrying it

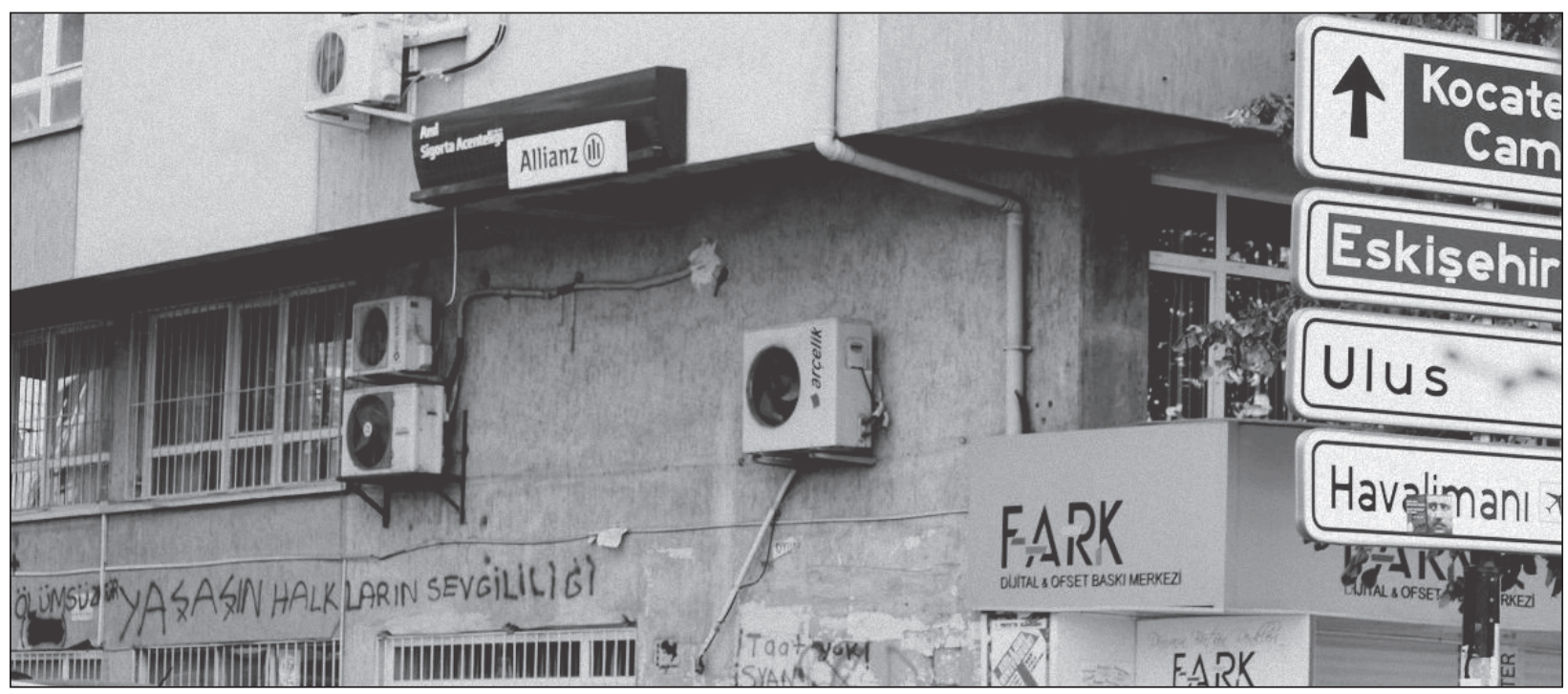

Figure 14. Writings on the walls and signboards.

Photograph by: Duygu Cihanger Ribeiro.
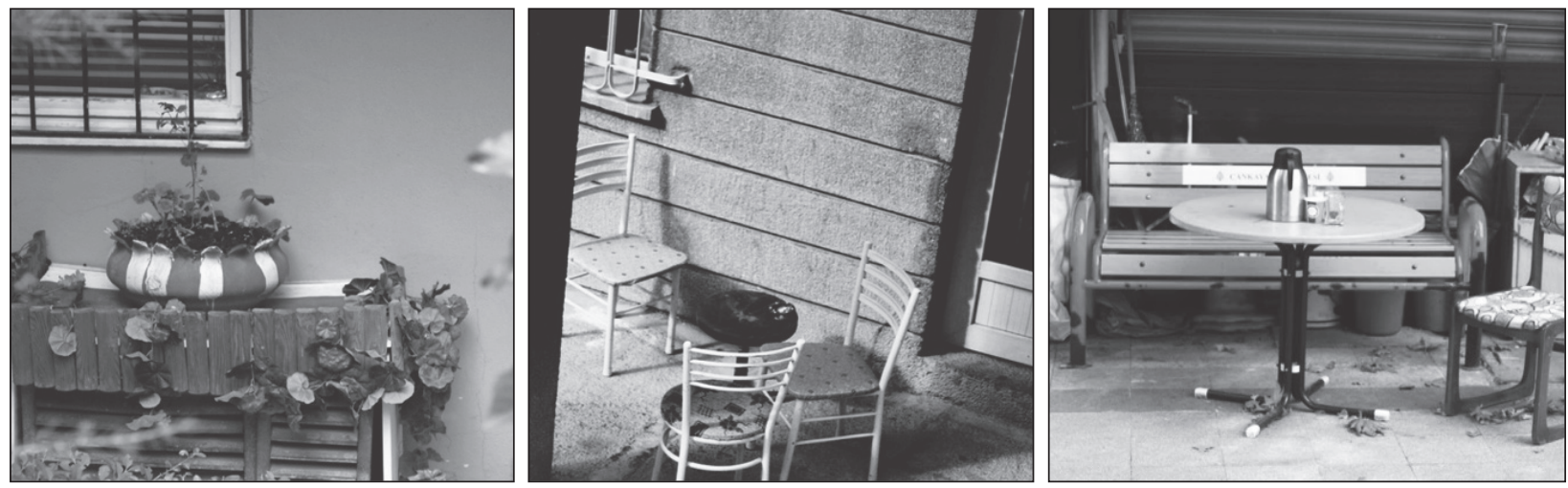

Figure 15. The objects of personalization of urban space.

Photograph by: Duygu Cihanger Ribeiro. 
into a more tangible urban public sphere is expected to bring new theoretical discussions for a human-centered urban design. Moreover, the rhythmanalysis through its constant, transient rhythms and ruptures connect the relatively static nature of urban form to the urban social rhythms. Moreover, this approach brings together ordinary and extraordinary everydayness through empirical observations and visual analysis. These findings enrich the studies of urban ethnography in existing literature. For instance, Whyte (1980) only documents people's use of space and tries to grasp the existing spatial qualities for certain activities. The case study in Yüksel Street shows that capacity of people to transform an intentionally designed urban setting showing that the "lived space" is more than a philosophical concept as developed by Lefevbre (1991), Soja (1996) and Merrifield (2006). The real-life examples present the roles of people in using and transforming the space provides a solid research example theoretically discussed by Stanek (2011) for the possibilities of an empirical study on the lived space.

In particular, the findings of the field study in Yüksel Street contribute to the discourse on social and physical production of urban space. Initially, the urban setting and history provide a framework any detailed empirical observation of everyday life and space in this area. The unfolding of the archive presents the intermingled and transformative relationship between the socio-political scenes and urban form. The social realities either adapt or push the premeditations of an urban blueprint plan as Yüksel Street has developed following these internal dynamics along with urban professionals' decisions throughout its development history street was initially planned as a greenway accommodating detached singlefamily houses in gardens and offering a quiet lifestyle when it was first developed. However, the open space prevailed in the site gradually diminished since then, and everyday life has become more complex in periods of circa twenty years. Today, the street accommodates a complex organization of social setting, pedestrian flow, daily and night-time street vending activities, political protests and police control.

The field visits and following studies show that the physical form is not directly or visibly affected by these changes. Still, the poiesis, making, and creation of urban space, discloses the social and spatial details in the site due to the human use through everyday walks, daily observations, being attentive to urban rhythms and alternative aesthetics in physical space. Firstly, rhythmanalysis explored the temporal dimension of urban space in Yüksel. The findings of the constant movement of pedestrians, the transient social uses of certain spaces along the street presented the ordinary and somewhat expected qualities of everyday life. However, the in-between spaces and niches along the street seem to accommodate most of the transient rhythms where people tend to spend time out activities or socialize. The deduction is that people create their own (ephemeral) spaces even though these socialization spaces are not provided through urban design policies. In the second section of data analysis of everyday observations, the emergent urban aesthetics present that the human impact is not always ephemeral at all.

The change in the form of the street has not always been substantial as the historical analysis of morphology presents. However, the small-scale interventions by people do not only transform the perceptual and physical morphology of the street but also bring life to it. Thus, the lived space in the sense of Yüksel has actual urban time and form which is open to empirical analysis. The ordinary spaces created through use are various such as wall fronts, in-between spaces of public and private uses, elevations such as garden walls or stairs, lastly the elements of personalization such as text, images, and objects placed along the street. These physical imprints coating the designed street layout are important to notice and record to develop ethnographic research in urban studies. The urban social theory and methodological approach proposed in this study presents the empirical dimension of the post-design process theorized by Alexander Cuthbert (2007). Furthermore, the emphasis of locality and site-specificity of the research contributes to the similar discussions mainly proceeded in the European context. (Franck and Stevens, 2007; Aelbrecht, 2016). The findings from Yüksel Street on the connection between designed space and the lived space promises a theoretical and methodological approach developed from the site.

Moreover, in the sense of a further urban design policy, they give clues about the most preferred areas by people, their aesthetic understanding, and the way people represent themselves in the public space. However, it is not possible to resolve the social dimension of urban space through single research. Likewise, the terms of everyday 
life lived space and social production of space are directly associated with the social discourse which is theoretical and philosophical. In the empirical sense, this research on the poiesis of everyday life and space in Yüksel Street opens up a perspective to deal with these terms in urban planning and design scholarship with a direct emphasis on the urban form and physical space. Still, the social and physical is in an ever-developing relationship, always transforming and creating new urban conditions. From an urban design perspective welcoming these living forms and rhythms of space is a critical concern since the subjectivity and complexity of the living conditions would result in the uncontrolled development. In the case of Yüksel Street, the primary outcome of the spaces for socialization and the design qualities, elements and operations deduced from the traces of personalization in the street can still provide the basic tools for a future urban design study in the site which fosters the poiesis in urban space by its users.

\section{References}

Aelbrecht, P. S. (2016). Fourth places: the contemporary public settings for informal social interaction among strangers. Journal of Urban Design, 21(1), 124-152.

Akış, T. (2001). Urban space and everyday life: Walking through Yüksel pedestrian district. Unpublished Master's Thesis, Middle East Technical University, Department of Architecture, Ankara.

Agamben, G. (1999). The man without content. Stanford, CA: Stanford University Press.

Alexander, C. (1979). Timeless way of building. Oxford: Oxford University Press.

Augoyard, J. F. (2007). Step by step: everyday walks in a French urban housing project. Minneapolis: University of Minnesota Press.

Batuman, B. (2006). Turkish urban professionals and the politics of housing, 1960-1980. METU Journal of Faculty of Architecture, 23(1), 59-81.

Bayat, A. (1997). Street politics. Columbia University Press.

Bayraktar, N. (2013). Tarihe eş zamanlı tanıklık: Ulus ve Kızılay meydanlarının değişim süreci. Ankara Araştırmaları Dergisi, 1(1), 20-35.

Bentley, I. (1985). Responsive environments: a manual for designer. London: Architectural Press

Bilsel, G. (1977). Ankara'nın kentsel gelişmesinde yıkılıp yeniden yapılma yoluyla yükselip yoğunlaşma olgusu ve yaygınlaşma seçeneği. Mimarlık, 03(152), 53-59.
Borden, I. (2001). Skateboarding, space and the city: architecture and the body. London: Bloomsbury/Berg Academic.

Boudon, P. (1972). Lived-in architecture. The MIT Press Classics.

Çalışkan, O. (2014). Pattern formation in urbanism: A critical reflection on urban morphology, planning, and design. Unpublished Ph.D. Thesis, Delft University of Technology, Delft.

Cengizkan, A. (2004). Ankara'nın ilk planı 1924 - 25 Lörcher planı. Ankara Enstitüsü Vakfı; Arkadaş Yayıncılı.

Certeau, M. D. (1984). The practice of everyday life. Berkeley: University of California Press.

Cihanger, D. (2018). Spaces by people: an urban design approach to everyday life. METU Journal of Faculty of Architecture, 35(2), 55-76.

Cuthbert, A. (2007). Urban design: requiem for an era - review, and critique of the last 50 years. Urban Design International, 12(4), 177-223.

Çelik Z, Favro, D., and Ingersoll, R. (Eds.). (1994). Streets: critical perspectives on public space. Berkeley: University of California Press.

Dinçer, Ö. (2016). Sokak siyasetinin bir örneği olarak Yüksel ve Konur sokaklar. İlef Dergisi 3(2), 55-77.

Doğan, İ. (1994). Bir alt kültür olarak ankara yüksel caddesi gençliği. Ankara: Kültür ve Turizm Bakanlığı.

Elden, S. (2004). Understanding Henri Lefebvre: theory and the possible. London: Continuum Press.

Evyapan, G. (1981). Kentleşme olgusunun hızlanması nedeniyle yapılar yakın çevresi düzeyinde açık alan ve meknaların değişimi. Ankara: ODTÜ Mimarlık Fakültesi.

Franck, K. A., Stevens, G. (2007). Loose space: possibility and diversity in urban life. London: Routledge.

Güneş, G. (2013). İkinci Dünya Savaşı yıllarında Ankara'da günlük yaşam. Ankara: Alter.

Habraken, N.J. (1998). The structure of the ordinary. Cambridge: The MIT Press.

Hall, S. (2012). City, street, and citizen: the measure of the ordinary. London and New York: Routledge.

Heidegger, M. (1971). Building dwelling thinking from poetry, language, thought. New York: Harper Colophon. Books.

Highmore, B. (2002). Everyday life and cultural theory. London: Routledge.

Jacobs, J. (1961). The life and death of great American cities. New York. Random House.

Jaussely, L. (1929). P. Rapport explicatie du plan d'Angora (Turquie). Ankara Document Collection (Inventory no: 0119). Koç University VEKAM Archive, Ankara. 
Jones, A. (2018). Everyday without exception? Making space for the exceptional in contemporary sociological studies of streetlife. The Sociological Review, 66(5), 1000-1016.

Karaosmanoğlu, Y. K. (1981). Ankara (Original work published 1934). İstanbul: Birikim.

Lansere, Y.Y. (2004). Ankara yazi: bir Sovyet sanatçısının 1922 notlar ve resimleri [Summer in Ankara: 1922 Notes and drawings of a Soviet artist]. Kaynak.

Lefebvre, H. (2004). Rhythmanalysis: space, time and everyday Life (Original work published 1992). London: Bloomsbury Publishing.

Lefebvre, H. (1991a). Critique of everyday life: foundations for a sociology of the everyday. London: Verso Publishing.

Lefebvre, H. (1991b). The production of space. Oxford: Blackwell Publishing.

Madanipour, A. (1996). Design of urban space: an inquiry into a socio-spatial process. New York: Wiley.

Marshall, S. (2005). Streets and patterns. London: Spon Press.

Merrifield, A. (2006). Henri Lefebvre: a critical introduction. London: Routledge.

Shields, R. (1999). Lefebvre, love, and struggle: spatial dialectics. New York: Routledge.
Soja, E. (1996). The socio-spatial dialectic, Annals of the Association of American Geographers, 70(2), 207-225.

Soysal, S. (1973). Yenişehir'de bir öğle vakti. İstanbul: İletişim.

Stanek, L. (2011). Henri Lefebvre on space. architecture, urban research, and the production of theory. Minneapolis: University of Minnesota Press.

Özcan, E. (2016). Making an inventory of the stall's panorama: peddlars (Ankara Yüksel Case). Akademik Sosyal Araştırmalar Dergisi 4(25), 341-358.

Tanyer, T. (2006). Scenes from the social life of Ankara during the early republican period. Ankara: VEKAM.

Usal, S.S. (2014).1960'larda bir departmanlı magaza tasarımının kadınların yasam tarzı baglamında incelenmesi: Kızılay Gima. Mimarlik, 378, 53-59.

Vaneigem, R. (1983). Revolution of everyday life. London: Rebel Press.

Whyte, W. (1980). The social life of small urban spaces. New York: Ingram.

Wunderlich, F., M. (2013). Place-temporality and urban placerhythms, in urban analysis and design: an aesthetic akin to music. Journal of Urban Design, 18(3), 383-408.

Yavuz, F. (1952). Ankara'nın imarı ve şehirciligimiz. Ankara: Faculty of Political Sciences. 
